\title{
The Hampshire-Berkshire focus of $L 120 Q$ anticoagulant resistance in the Norway rat (Rattus norvegicus) and field trials of bromadiolone, difenacoum and brodifacoum
}

Article

Accepted Version

Buckle, A. P., Jones, C. R., Rymer, D. J., Coan, E. E. and Prescott, C. V. (2020) The Hampshire-Berkshire focus of L120Q anticoagulant resistance in the Norway rat (Rattus norvegicus) and field trials of bromadiolone, difenacoum and brodifacoum. Crop Protection, 137. 105301. ISSN 0261-2194 doi: https://doi.org/10.1016/j.cropro.2020.105301 Available at https://centaur.reading.ac.uk/92147/

It is advisable to refer to the publisher's version if you intend to cite from the work. See Guidance on citing.

Published version at: http://dx.doi.org/10.1016/j.cropro.2020.105301

To link to this article DOI: http://dx.doi.org/10.1016/j.cropro.2020.105301

Publisher: Elsevier

All outputs in CentAUR are protected by Intellectual Property Rights law, including copyright law. Copyright and IPR is retained by the creators or other copyright holders. Terms and conditions for use of this material are defined in the End User Agreement. 


\section{www.reading.ac.uk/centaur}

\section{CentAUR}

Central Archive at the University of Reading

Reading's research outputs online 
1 The Hampshire-Berkshire focus of L120Q anticoagulant resistance in the Norway rat (Rattus

2 norvegicus) and field trials of bromadiolone, difenacoum and brodifacoum

3 Alan P. Buckle, ${ }^{*}$ Clare R. Jones, David J. Rymer, ${ }^{\dagger}$ Emily E. Coan ${ }^{\S}$ and Colin V. Prescott

4 Vertebrate Pests Unit, School of Biological Sciences, The University of Reading, Reading, RG6 6AS, UK

\section{Abstract}

6 Anticoagulant resistance has been present in Norway rats (Rattus norvegicus) in Hampshire and

7 Berkshire for forty years. All first-generation anticoagulants and two of the second generation,

8 bromadiolone and difenacoum, are resisted by rats carrying the L120Q single nucleotide

9 polymorphism (SNP). A regulatory restriction on the use of resistance-breakers brodifacoum,

10 difethialone and flocoumafen in the UK effectively prevented their use against Norway rats for more

11 than 30 years. During this time, L120Q spread from original localised foci eventually to cover most

12 of central-southern England; with other more dispersed foci elsewhere in the UK. We summarise research on L120Q Norway rats and the field performance of anticoagulant baits against them. Bromadiolone (50 ppm), difenacoum (50 ppm) and brodifacoum (23 ppm) baits were each applied on two farmsteads where it had been established that Norway rats carried the L120Q SNP. Preliminary DNA resistance tests conducted at the farms found only one of 107 rats to be susceptible and $86.9 \%$ to be homozygous resistant. The bromadiolone and difenacoum applications were either partially or wholly ineffective; brodifacoum treatments were fully effective. Quantities of active substances used varied between farms and substances; but more bromadiolone and difenacoum baits were applied than brodifacoum baits during the treatments. Results confirm the high incidence of resistance and support advice that bromadiolone and difenacoum should not be used against the L120Q SNP. Prolonged use of resisted anticoagulants has resulted in a high prevalence of homozygosity and resistance spread. Failed treatments result in prolonged feeding on anticoagulant bait and leave Norway rats alive carrying, presumably, high residues. It remains to be 
seen whether the use of now-permitted effective substances, and the introduction of a rodenticide stewardship regime, will curtail the spread of resistance and reduce anticoagulant residues in wildlife.

KEY WORDS: Anticoagulant resistance, Rattus norvegicus, second-generation anticoagulant rodenticide, $\mathrm{L} 120 \mathrm{Q}$, rodent control, non-target wildlife

* Corresponding author email: alan@alanbuckelconsulting.com

Present addresses:

${ }^{\dagger}$ Innovation Impact and Business, Tremough Campus, University of Exeter, Cornwall, TR10 9FE.

$\S 6$, Manners Road, Woodley, Reading, Berkshire, RG5 3EA.

\section{INTRODUCTION}

The Norway rat (Rattus norvegicus) anticoagulant resistance focus in central southern England was first identified in 1969 (Greaves and Rennison, 1973) and came to be known as Hampshire difenacoum resistance (Greaves and Cullen-Ayres, 1988). The focus was then considered to be 'relatively inconsequential' but was recognised probably to be caused by a 'different genotype' to those found in the better-known Scottish, Welsh and Kent foci. Fifty years later this focus has become one of the most extensive and severe anticoagulant resistance phenomena found anywhere in the world, due to the presence of the L120Q (leucine120glutamine) single nucleotide polymorphism (SNP) (Pelz and Prescott, 2015; Boitet et al., 2018). Presently, the focus covers almost all of central-southern England, and L120Q rats are increasingly found more widely across the UK (Jones et al., 2019) Since their discovery, resistant rats from this part of the UK have been studied extensively, both in the laboratory and field, in attempts to resolve questions about the genetic nature of this resistance, the efficacy of anticoagulant rodenticides and behavioural traits that appear to co-exist with it. All 
of these questions remain only partially answered. A laboratory feeding test for the identification of resistance to difenacoum was developed as a precautionary measure on the assumption that resistance to this, then, newly-introduced substance was likely to emerge among Norway rats sooner or later (Redfern and Gill, 1978). This was prescient because the failure of difenacoum to control Norway rats on farms on the north Hampshire-Berkshire border was soon reported. Rats taken from this area, and tested using the new resistance feeding test, were confirmed to be difenacoum-resistant, one female survived the consumption of $123.9 \mathrm{~g}$ of difenacoum bait (37.3 mg.kg-1 of the active substance) (Redfern and Gill, 1978).

Two further studies were conducted; one to identify the geographical extent of the new resistance focus and another to test the efficacy of three newly-developed anticoagulants within it. The focus was found to be mainly within the boundaries of lines joining the Berkshire and Hampshire conurbations of Reading, Newbury, Andover, Winchester and Alton (Greaves et al., 1982a). Field trials showed that, while bait containing 50 ppm difenacoum was largely ineffective within the focus, the efficacy of $50 \mathrm{ppm}$ bromadiolone was also substantially impaired (Greaves et al., 1982b). Only $20 \mathrm{ppm}$ brodifacoum baits were fully effective but control operations using this active substance took longer than normal, suggesting an albeit lesser degree of resistance.

The results of these early studies were relatively unequivocal until resistance factors were derived from feeding tests for Norway rats from the 'Hampshire' focus as follows: difenacoum 3.9 (males) and 2.7 (females), bromadiolone 1.5 (males) and 2.9 (females), brodifacoum 2.0 (males and females) (Greaves and Cullen-Ayres, 1988). Resistance factors were somewhat higher for a laboratory-bred 'selected line' created by crossing and back-crossing to select for anticoagulant resistance. However, resistance factors of this magnitude would not normally be expected to result in the degree of practical treatment failure observed (Greaves et al., 1982b), and factors of a similar magnitude for the same compounds were reported in other foci, such as Scotland and Wales, but without any similar diminution of practical treatment efficacy (Greaves and Cullen-Ayres, 1988). 
Several explanations are conceivable for these observations but none is wholly convincing. They include the presence of a behavioural trait that prevented feeding on rodenticide baits in Hampshire resulting in reduced intake of the active substances, a second additive resistance mechanism not related to the conventional resistance gene and the possible selection in field populations of an advanced form of resistance, caused by the repeated use of resisted rodenticides, which meant that the laboratory strains tested by Greaves and Cullen-Ayres had been superseded. It subsequently transpired that each of these explanations was at least partially relevant.

Following the development of the 'selected line', carrying the strongest resistance phenotype then known (Greaves and Cullen-Ayres, 1988), a resistance feeding test was developed for one of the most potent anticoagulants available, brodifacoum, involving bait containing $5 \mathrm{ppm}$ of the active substance (Gill and MacNicoll, 1991). Animals that survived consumption of this bait for seven days were termed 'brodifacoum-resistant'. The somewhat illogical implication of this was that rats declared 'brodifacoum resistant' were likely to be fully susceptible during field operations because these employed commercial baits carrying 50 ppm of the active substance. Several hundred wildcaught rats from the difenacoum resistance area were tested using the brodifacoum resistance test and a single male survivor was used to found a selected 'brodifacoum-resistant' laboratory strain. The form of resistance it exhibited was termed 'low-grade' and, as the farms from which these animals were taken were in Berkshire, the strain came to be called "Berkshire-resistant" (Gill et al., 1992). However, breeding studies showed that this resistance was not genetically stable in the same way as other resistance mutations known at the time (Gill et al., loc. cit.).

Research also continued in the field, particularly to investigate the influence of rat behaviour on treatment efficacy within the difenacoum resistance focus. Differences were found between the responses of rats to both poisoned and unpoisoned baits in the Welsh and Hampshire resistance areas (Quy et al., 1992). Rats readily consumed novel foods such as rodenticide baits on Welsh farms, with consequent rapid control of entire infestations. While in Hampshire rats were often 
reluctant to consume novel foods, resulting in control being delayed for many weeks. There was also frequent failure on these farms to achieve complete control. These differences were attributed to rat behavioural responses to farming practices and the structures of the farmsteads themselves. In Wales, mixed arable and livestock farms (mainly dairy and sheep) present highly disturbed environments, where food sources and harbourage change frequently. In such situations, rats quickly overcome their suspicion of novel objects and new foods to acquire the resources they need. There was little animal husbandry on many Hampshire farms and farmsteads presented habitats where food sources, often bulk grain flat-stores (i.e. large quantities of cereals held in metal-sided bins on concrete floors), were stable over long periods. Rats established feeding patterns undisturbed and were reluctant to divert their feeding onto novel food, such as rodenticide baits, and away from known, stable and abundant alternative food resources (Quy et al., loc. cit.).

The UK regulatory framework throughout this period, and indeed until 2016, was one wherein only bromadiolone and difenacoum were effectively available for the control of anticoagulant-resistant Norway rats. Concerns about the potential environmental effects of the more potent resistancebreakers, brodifacoum, flocoumafen and, latterly, difethialone, had resulted in their restriction to use indoors only (HSE, 2012). This restriction virtually precludes their use against rat infestations because usually the greater part of these reside outdoors (Buckle, 2013). Finally, carefully monitored applications of bromadiolone bait on a farm in West Berkshire proved entirely ineffective, with $830 \mathrm{~kg}$ of bait consumed on the farm over an eight month period, resulting in no measurable reduction in the size of the infestation (Quy et al., 1995). The use of bait markers revealed that one rat survived the consumption of at least $450 \mathrm{~g}$ of bromadiolone bait. Such a massive environmental emission of a second-generation anticoagulant, when replicated elsewhere in anticoagulant resistance foci, because the more potent resistance-breaking compounds could not be used, may go some way to explain both the large current extent of resistance foci in the UK and the prevalence of residues of bromadiolone and difenacoum in UK wildlife (Buckle, 2013; Shore et al., 2015; Jones et al., 2019). 
The genetic basis of Norway rat anticoagulant resistance mutations was revealed to be a series of SNPs in the VKORC1 gene located on chromosome 1 (Rost et al., 2004). Pelz and his co-workers showed that rats from the Hampshire-Berkshire focus possess the L120Q SNP (Pelz at al., 2005; Pelz and Prescott, 2015). However, the research cited above appeared to show that there is more than one resistance phenotype at this focus, with Berkshire-resistant rats having a higher level of resistance to anticoagulants than Hampshire-resistant rats but each possessing the same resistance SNP. The presence of a second resistance mechanism was postulated to explain this (Buckle, 2013), and it was later found that elevated CYP450-oxidative metabolism, leading to an accelerated anticoagulant detoxification, is involved in the Berkshire phenotype (Boitet et al., 2018). A mechanism of enhanced metabolism and clearance of anticoagulants, involving CYP450 enzymes, was also found to explain some characteristics of bromadiolone resistance in Norway rats from Denmark (Markussen et al., 2008).

The purpose of the field trials described here was to test the efficacy of proprietary bromadiolone and difenacoum formulations against the anticoagulant-resistant Norway rat genotype present at the heart of the Hampshire/Berkshire resistance focus in 2008. No similar trials had been conducted since 1991 (Quy et al., 1995). For the first time, the treated populations were screened for the resistance mutation they carried using the (then) new DNA sequencing method (Pelz at al., 2005). After the difenacoum and bromadiolone trials had been completed, the intention was to test the effectiveness of a proprietary brodifacoum formulation in anticipation that this more potent active substance might offer both a practical solution to resistance in this focus and the potential to reduce wildlife exposure to second-generation rodenticides. However, since outdoor bait applications were needed, permission for the brodifacoum field trials was required from the UK biocides regulatory body, the Health and Safety Directorate (HSE). This permission was denied on the grounds that the risk to the environment of the two trials, acknowledged to be limited, was not justified by their anticipated scientific value. Therefore, the brodifacoum trials presented here could not be 
on brodifacoum (and consequently also on the other potent, resistance-breaking anticoagulants, difethialone and flocoumafen). In the interim period, the use of bromadiolone and difenacoum baits, shown in these trials to be largely ineffective, was the major anticoagulant intervention permitted to those whose premises were infested by resistant Norway rats. This likely had important consequences for resistance management, resistance spread and the exposure of wildlife to rodenticides (Daniells et al., 2011; Buckle, 2013).

Recent resistance surveys have revealed that the original Hampshire/Berkshire resistance focus has apparently spread widely from the areas where it was first discovered and now covers most of central southern England (Greaves and Rennison, 1973; Jones et al., 2019). There is also evidence of pockets of this resistance in many other parts of the UK, including East and West Sussex, Wiltshire, Somerset, Devon, Monmouthshire, Yorkshire and the counties of East Anglia (Rodenticide Resistance Action Committee http://www.rrac.info/). It is impossible to know whether these have become established either as a result of the transportation of resistant rats from original foci or from de novo mutation events. In any case, the lessons learned about the use of rodenticides against rats carrying the L120Q mutation during this study are now more widely relevant.

\section{MATERIALS AND METHODS}

2.1 Trial sites

General

The trial sites were working farms in West Berkshire and north-west Hampshire, within the L120Q resistance focus (Jones et al., 2019). Each site differed from the others in the composition of livestock and farming practices (see below), although they were typical of farm enterprises in the area that had been previously used for field trials of anticoagulant rodenticides (Greaves et al., 1992b; Quy et al., 1995; Cowan et al., 1995). All were infested with Norway rats, living predominantly outside the farm buildings, although in very close proximity to them. Another 
common feature was that there were plentiful food sources and harbourage for rats, although few of these could be eliminated given conventional farm practices involving ad libitum feeding of livestock and the methods of storing cereal grains on-farm. All of the infestations were circumscribed with very little sign of movement of rats onto the farms from neighbouring areas, though in some places low-level infestations were to be found in neighbouring hedgerows, as is normal for the rural landscape of Hampshire and Berkshire. All who operated these enterprises had expended considerable resources in rodent pest management. These efforts mostly involved baiting with either the permitted difenacoum or bromadiolone baits, in conjunction with burrow fumigation and trapping. Two of the sites were under contract to a reputable commercial pest control company, but all had achieved only partially satisfactory control of rat infestations.

\section{Site 1. Large dairy unit, nr. Stockbridge, Hampshire}

The site comprised a large, modern milking parlour and four large open barns in which approximately 600 dairy cattle were housed in sheds set on a concrete apron. Other infested buildings included a feed store, concrete bunkers in which maize silage was stored, a vehicle shed and barns used for housing calves and storing straw bales. The moderate rat infestation was mainly feeding on the silage maize available from the cattle stalls and concrete bunkers. The site was very clean and well-kept, with limited availability of harbourage for rats. Rat burrows were mainly found on waste ground bordering the site, beneath the concrete foundations of buildings and areas of disturbed ground.

\section{Site 2. Small mixed farm, nr. Welford, West Berkshire}

The site involved a machinery barn, two smaller barns used for grain storage, a large barn used for vehicle parking and the storage of grain used in pheasant feeders and a Dutch barn with straw bales. In the centre of the site were two rows of pig-sties containing about 100 sows and piglets. The farmstead was in a poor state of maintenance, with large areas of overgrown vegetation around the 
site and between the buildings. Food was continuously available for the heavy rat infestation in the pig stalls, at a flat store of whole wheat grains used for pheasant feeding and from spillage in a granary and milling barn. Rats had found harbourage in and around the buildings and barns across the site.

Site 3. Large free-range poultry unit, nr. Stockbridge, Hampshire

The site comprised thirteen large free-range poultry sheds, with raised floors above compacted earth bases. The sheds accommodated approximately 15,000 birds and applied high standards of animal welfare, cleanliness and biosecurity. However, the moderate rat infestation had continuous access to food from the chicken feed hoppers in each of the poultry sheds and, to a limited degree, from the spillage at augers and feed silos across the site. A long hedge ran down the entire northeast border of the site with rat burrows along its length and there were rat runs and burrows around and under the poultry sheds.

\section{Site 4. Large mixed farm, nr. Wickham, West Berkshire}

The site comprised three large barns for pigs, cattle and sheep and further barns for machinery and equipment, grain and straw bales. In addition there was a neighbouring hanger for light aircraft and several smaller buildings with varying uses. The farm was well-maintained although there were neglected areas and grain spillage in a storage barn and mill. There was evidence of rat infestation across the site; although mainly restricted to the farm buildings, there was evidence of low-level infestation in hedgerows leading away from the building in which pigs were housed.

\section{Site 5. Small dairy unit, nr. Reading, West Berkshire}

The site consisted of an office building, with a large shed for the intensive feeding and milking of cattle and a smaller shed for dairy cows. Pheasants were present throughout the site, particularly where there was woodland cover. There was evidence of rats being present, with runs and burrows 
221 in several areas and live rats seen around the site. Food resources for rats were available at the site

222 at feeding troughs provided for sheep and cattle.

224 The site comprised a residential house, an adjacent workshop, a large open pen for chickens and geese, and four barns which housed cows, sheep, hay and straw bales. There were abundant signs of a substantial rat infestation, with rat runs and rat burrows in all areas and with live rats frequently seen. Feeding troughs for sheep, cattle and chickens gave rats access to feed and feed stored in polymer bags in one of the barns was also accessible.

Following preliminary site surveys, initial work was conducted on all of the farmsteads to obtain information on the resistance status of their Norway rat infestations prior to the commencement of the bait applications. Blood-clotting response (BCR) tests were conducted on rats from four of the farms (sites 1-4) during $2009 / 2010$ to assess the degree of resistance to anticoagulants they exhibited and, in particular to compare current resistance factors with those published previously based on feeding tests (Greaves and Cullen-Ayres, 1988). For this, a standard protocol was employed which involved the administration by gavage of solutions containing various concentrations of bromadiolone and difenacoum, subsequent removal of blood samples under anaesthesia and assessment of blood clotting responses (BCR) (Prescott et al., 2007).

Tissue samples from rats on all of the farms were taken for DNA extraction and sequencing. On four of the farms (sites 1-4) rats were trapped prior to the treatments specifically for this purpose. Dead rats were collected both prior to and during the progress of the poison baiting treatments on the other two farms (sites 5 and 6 ). The procedures used to detect the presence or absence of anticoagulant resistance DNA mutations were similar to those described by Prescott et al. (2007) 
and, although only the $\mathrm{L} 120 \mathrm{Q}$ mutation was subsequently found, all other rat resistance mutations known to be present in the UK would have been found had they been present.

\subsection{Test substances}

247 The rodenticide bait formulations tested in the trials are shown in Table 1. Two of the baits were commercially available pellet formulations, one contained 50 ppm bromadiolone (Contrac ${ }^{\circledR}$ ) and the other 50 ppm difenacoum ( $\left.\operatorname{Ratak}^{\circledR}\right)$. The remaining two formulations both contained brodifacoum as an active substance. One was a $20 \mathrm{~g}$ wax block experimental formulation, containing a nominal 23 ppm of the active substance, and the other a commercial pellet formulation containing the same concentration of brodifacoum $\left(\operatorname{Talon}^{\circledR}\right)$. All the test baits, both proprietary and experimental, contained 10 ppm of the human taste deterrent denatonium benzoate (Kaukeinen and Buckle, 1992).

\begin{tabular}{|l|l|l|l|l|l|}
\hline Bait type & $\begin{array}{l}\text { Active } \\
\text { substance }\end{array}$ & $\begin{array}{l}\text { Active } \\
\text { substance } \\
\text { conc. (ppm) }\end{array}$ & $\begin{array}{l}\text { Trial } \\
\text { site(s) }\end{array}$ & $\begin{array}{l}\text { Quantity of } \\
\text { bait applied } \\
\text { per baiting } \\
\text { point (g) }\end{array}$ & $\begin{array}{l}\text { Replenishment } \\
\text { frequency }\end{array}$ \\
\hline Pellet (commercial) & difenacoum & $50 \mathrm{ppm}$ & 1 and 2 & $100-300$ & Twice weekly \\
\hline Pellet (commercial) & bromadiolone & $50 \mathrm{ppm}$ & 3 and 4 & $150-300$ & Twice weekly \\
\hline $\begin{array}{l}\text { Wax block }(20 \mathrm{~g}) \\
\text { (experimental) }\end{array}$ & brodifacoum & $23 \mathrm{ppm}$ & 5 & $20-60$ & $\begin{array}{l}\text { Three times } \\
\text { weekly }\end{array}$ \\
\hline $\begin{array}{l}\text { Pellet (commercial) } \\
\text { brodifacoum }\end{array}$ & $23 \mathrm{ppm}$ & 6 & 50 & $\begin{array}{l}\text { Three times } \\
\text { weekly }\end{array}$ \\
\hline
\end{tabular}

Table 1. Rodenticide baits used, the concentrations of the active substance, application rates and the frequency of bait replenishment in the six field trials. were conducted during the period February 2009 to January 2010. Trials 5 and 6 were conducted from April to December 2016. 
The field trial protocol closely followed that used in similar studies of anticoagulant rodenticide efficacy (Endepols et al., 2011; Buckle et al., 2012) and was in accordance with published guidelines from international agencies including the European and Mediterranean Plant Protection Organisation (EPPO, 1998), the European Commission (EC, 2011) and the European Chemicals Agency (ECHA, 2017a). The protocol was based on the application of poisoned baits according to their regulatory label requirements, or as otherwise advised by the manufacturers. Evaluations of efficacy relied on two different indirect assessments of the size of the rodent infestation applied in a similar manner before and after the treatment, namely census baiting and the measurement of tracking activity (Quy et al., 1993). In preparation for the field trials, the six sites were surveyed and scale maps were drawn. A thorough search of each site was conducted for the bodies of any Norway rats and non-target animals prior to bait applications and any bodies found were removed.

The field trial schedule comprised three main phases, each separated from the other by a lag period during which no activities were undertaken at the sites. The first phase involved a pre-treatment census, generally four-days in duration, in which census baiting and tracking were used to estimate the initial size of the rat infestations. The numbers of census bait points and tracking patches set out at the six sites are shown in Table 2. On the first day of the pre-treatment census, the wooden census bait trays were filled with $200 \mathrm{~g}$ of whole dry wheat, and the sand tracking patches, each approximately $100 \mathrm{~mm}$ by $150 \mathrm{~mm}$, were smoothed over. The census bait was weighed $( \pm 1 \mathrm{~g})$ and replenished daily. Where complete takes of census bait occurred, the quantity of census bait put down at replenishment visits was doubled. This resulted in $800 \mathrm{~g}$ of bait on some bait points in heavily infested areas. The tracking patches were recorded and smoothed over daily for four consecutive days. The tracking patches were scored using the following scale: $0=$ no signs of rodent tracks; $1=1-5$ rodent tracks, $2=>5$ tracks and up to $25 \%$ of patch covered with footprints; $3=26-$ $95 \%$ covered; $4=>95 \%$ covered. A lag period of not less than four days was used to separate the pre-treatment census period from poisoned baiting to permit the rats to return to their usual foods and feeding places. 


\begin{tabular}{|c|l|l|c|c|c|}
\hline Site & Dates of trial & Active substance & $\begin{array}{c}\text { No. tracking } \\
\text { patches }\end{array}$ & $\begin{array}{c}\text { No. census bait } \\
\text { points }\end{array}$ & $\begin{array}{c}\text { No. poisoned } \\
\text { bait points }\end{array}$ \\
\hline 1 & $13.02 .2009-08.05 .2009$ & difenacoum & 45 & 58 & 57 \\
\hline 2 & $26.10 .2009-24.01 .2010$ & difenacoum & 39 & 82 & 90 \\
\hline 3 & $13.02 .2009-21.04 .2009$ & bromadiolone & 54 & 78 & 77 \\
\hline 4 & $26.10 .2009-24.01 .2010$ & bromadiolone & 46 & 94 & 97 \\
\hline 5 & $18.04 .2016-29.07 .2016$ & brodifacoum & 35 & 50 & 55 \\
\hline 6 & $05.05 .2016-23.12 .2016$ & brodifacoum & 32 & 50 & $90^{*}$ \\
\hline
\end{tabular}

Note: $* 41$ rat burrows were also baited for a 13 -day period.

Table 2. The dates of trials, numbers of tracking, census bait and poisoned bait points used on the six

farms.

The second phase was that of poisoned bait application. The difenacoum and bromadiolone baits

were applied according to the regulatory labels found on the product packs. These permitted a

range of bait quantities (100-300g) to be placed at each bait point. Initial bait point sizes were $100 \mathrm{~g}$

per point but this quantity was increased either when complete takes occurred or when the take of

bait at a replenishment visit was found to have approached a complete take. Conversely, when

takes of bait declined the quantity of bait set out was reduced to the minimum permitted. The

The sites of the poisoned bait placements once again followed label instructions and were determined according to the intensity and distribution of signs of rat activity so that, so far as possible, all rats present had access to a nearby baiting point. Bait points were protected with materials available at the sites, such as pipes, bricks, wooden beams, corrugated metal sheeting and other materials. The use of locally-available materials for securing baiting points provides more rapid and greater uptake of bait than from purpose-made tamper-resistant bait boxes (Buckle and Prescott, 2011). However, specially-constructed wooden bait boxes (measuring approximately $31 \times 22 \times 14.5 \mathrm{~cm}$, with two rectangular entrances of approximately $7.5 \times 5 \mathrm{~cm}$ ) were used where insufficient material for robust protection of baits was found at the sites. Plastic bait boxes were also used, having approximate dimensions of $27 \times 18 \times 12 \mathrm{~cm}$, with two circular entrances with a 
diameter of $9 \mathrm{~cm}$. On some sites, when it became apparent that rats were present but were reluctant to feed from the covered bait stations, some baits were put directly into rat burrows. All bait points were inspected according to the treatment schedule and, at each visit, the remaining bait was weighed and replenished when necessary. An assessment of tracking activity continued throughout the poison baiting period, with recorded track scores being the aggregate score over the several days that separated baiting visits.

The trials ended with the completion of the third phase, the post-treatment census. This was conducted in a manner that was as similar as possible to that used in the pre-treatment census.

The basis for the calculations of the efficacy of treatments was a comparison between information obtained in the pre- and post- treatment census periods as follows (EPPO, 1998):

$\%$ efficacy $=$ pre-treatment activity - post-treatment activity $* 100$

pre-treatment activity

\section{RESULTS}

\subsection{Resistance tests}

Resistance tests based on BCR methodology (Prescott et al., 2007) were conducted to estimate the magnitude of resistance to second-generation anticoagulants at four of the trial sites (Table 3). Female animals were given a dose eight times and six times greater than the susceptible $E D_{50}$ for bromadiolone and difenacoum respectively, and male animals were given a dose three times the susceptible $E D_{50}$ for both active ingredients and, 24 hours later, a high proportion of the animals were found to be non-responders. In almost all cases, the percentage of non-responders was greater than 50\%, thus indicating female RFs of at least 8 and 6 for bromadiolone and difenacoum respectively, and male RFs of at least 3 for both active ingredients; a magnitude of resistance that is greater than that previously reported for both males and females for these substances using feeding tests (Greaves and Cullen-Ayres, 1998). 


\begin{tabular}{|c|c|c|c|c|}
\hline $\begin{array}{l}\text { Trial } \\
\text { site }\end{array}$ & Active substance & $\begin{array}{l}\text { Sex and no. of } \\
\text { animals tested }\end{array}$ & $\begin{array}{c}\text { Doses } \\
\text { administered }\end{array}$ & $\begin{array}{c}\% \text { non- } \\
\text { responders }\end{array}$ \\
\hline \multirow[t]{4}{*}{1} & \multirow[t]{2}{*}{ bromadiolone } & Female $(n=10)$ & $\begin{array}{l}5.00 \mathrm{mg} \cdot \mathrm{kg}^{-1} \\
\left(8 \times \mathrm{xD}_{50}\right)\end{array}$ & 70.0 \\
\hline & & Male $(n=7)$ & $\begin{array}{l}1.41 \mathrm{mg} \cdot \mathrm{kg}^{-1} \\
\left(3 \times \mathrm{ED}_{50}\right)\end{array}$ & 71.0 \\
\hline & \multirow[t]{2}{*}{ difenacoum } & Female $(n=9)$ & $\begin{array}{l}4.74 \mathrm{mg} \cdot \mathrm{kg}^{-1} \\
\left(6 \mathrm{xED}_{50}\right)\end{array}$ & 44.4 \\
\hline & & Male $(n=6)$ & $\begin{array}{l}1.95 \mathrm{mg} \cdot \mathrm{kg}^{-1} \\
\left(3 \mathrm{xED}_{50}\right)\end{array}$ & 83.3 \\
\hline \multirow[t]{4}{*}{2} & \multirow[t]{2}{*}{ bromadiolone } & Female $(n=5)$ & $\begin{array}{l}5.00 \mathrm{mg} \cdot \mathrm{kg}^{-1} \\
\left(8 \times \mathrm{ED}_{50}\right)\end{array}$ & 60.0 \\
\hline & & Male $(n=5)$ & $\begin{array}{l}1.41 \mathrm{mg} \cdot \mathrm{kg}^{-1} \\
\left(3 \times \mathrm{ED}_{50}\right)\end{array}$ & 60.0 \\
\hline & \multirow[t]{2}{*}{ difenacoum } & Male $(n=5)$ & $\begin{array}{l}1.95 \mathrm{mg} \cdot \mathrm{kg}^{-1} \\
\left(3 \times \mathrm{ED}_{50}\right)\end{array}$ & 60.0 \\
\hline & & Female $(n=5)$ & $\begin{array}{l}4.74 \mathrm{mg} \cdot \mathrm{kg}^{-1} \\
\left(6 \mathrm{xED}_{50}\right)\end{array}$ & 40.0 \\
\hline \multirow[t]{3}{*}{3} & \multirow[t]{2}{*}{ bromadiolone } & Female $(n=5)$ & $\begin{array}{l}5.00 \mathrm{mg} \cdot \mathrm{kg}^{-1} \\
\left(8 \mathrm{xED}_{50}\right)\end{array}$ & 40.0 \\
\hline & & Male $(n=8)$ & $\begin{array}{l}1.41 \mathrm{mg} \cdot \mathrm{kg}^{-1} \\
\left(3 \times \mathrm{ED}_{50}\right)\end{array}$ & 100.0 \\
\hline & difenacoum & Female $(n=1)$ & $\begin{array}{l}4.74 \mathrm{mg} \cdot \mathrm{kg}^{-1} \\
\left(6 \mathrm{xED}_{50}\right)\end{array}$ & 100.0 \\
\hline \multirow[t]{4}{*}{4} & \multirow[t]{2}{*}{ bromadiolone } & Female $(n=6)$ & $\begin{array}{l}5.00 \mathrm{mg} \cdot \mathrm{kg}^{-1} \\
\left(8 \times \mathrm{xD}_{50}\right)\end{array}$ & 33.3 \\
\hline & & Male $(n=2)$ & $\begin{array}{l}1.41 \mathrm{mg} \cdot \mathrm{kg}^{-1} \\
\left(3 \times \mathrm{ED}_{50}\right)\end{array}$ & 50.0 \\
\hline & \multirow[t]{2}{*}{ difenacoum } & Female $(n=11)$ & $\begin{array}{l}4.74 \mathrm{mg} \cdot \mathrm{kg}^{-1} \\
(6 x \mathrm{xD} 50)\end{array}$ & 63.3 \\
\hline & & Male $(n=13)$ & $\begin{array}{l}1.95 \mathrm{mg} \cdot \mathrm{kg}^{-1} \\
\left(3 \mathrm{xED}_{50}\right)\end{array}$ & 53.4 \\
\hline
\end{tabular}

Table 3. The results of the blood clotting response tests conducted on rats from four of the six treated farms. Doses administered are shown as both absolute values and as multiples of the ED50 for fully susceptible animals. Dates of the trials are given in Table 2.

Table 4 provides a summary of the DNA resistance tests that were conducted on a total of 111 rats taken from the farms. Tissue samples from four rats could not be sequenced. Among the others, only one individual did not carry the L120Q SNP; thus the frequency of resistance on the six farms was $99.1 \%$. The incidence of homozygosity was also very high (86.9\%). Such results are likely to be obtained where there has been a prolonged selection for the resistance trait caused by the frequent use of resisted anticoagulants. 


\begin{tabular}{|c|c|c|c|c|c|c|}
\hline Site & $\begin{array}{c}\text { Number of } \\
\text { animals }\end{array}$ & $\begin{array}{c}\text { Wild type } \\
\text { (susceptible) }\end{array}$ & Heterozygous & Homozygous & $\begin{array}{c}\text { Sequencing } \\
\text { failed }\end{array}$ & $\%$ resistant \\
\hline 1 & 32 & 0 & 1 & 30 & 1 & 100.0 \\
\hline 2 & 27 & 0 & 3 & 24 & 0 & 100.0 \\
\hline 3 & 13 & 0 & 1 & 12 & 0 & 100.0 \\
\hline 4 & 20 & 0 & 2 & 18 & 0 & 100.0 \\
\hline 5 & 9 & 1 & 1 & 5 & 2 & 85.7 \\
\hline 6 & 10 & 0 & 5 & 4 & 1 & 100.0 \\
\hline totals & 111 & 1 & 13 & 93 & 4 & \\
\hline
\end{tabular}

341 Table 4. Results of DNA sequencing for the L120Q resistance mutation among rats taken from the

342 trial sites. Dates of the trials are given in Table 2.

$343 \quad 3.2$ Efficacy of rodenticide treatments

Site 1. Large dairy unit, nr. Stockbridge, Hampshire

The survey of the farm had revealed a widespread infestation across the site, with a particular centre of activity around the barn that housed the calf stalls, stacks of straw bales and farm machinery.

Therefore, the very low take of census bait of just $174 \mathrm{~g}$ on the first day of the trial was unexpected and indicated that the rats on the site were reluctant to switch their feeding to novel alternative foods. Census bait takes increased rapidly (Fig. 1), however, but it was considered by the fourth day, when the census would normally have been terminated, that bait take $(1.37 \mathrm{~kg})$ still did not provide a realistic assessment of the size of the population. Therefore, census baiting was conducted for a further two days at which time the daily consumption of wheat bait had increased to $2.20 \mathrm{~kg}$. It seems likely that the take of census bait would have continued to increase had the census been continued for longer and, therefore, the size of the initial infestation may have been underestimated. It was also noticeable throughout the census that almost all bait consumption was from bait stations constructed from natural materials and very few takes were recorded from bait boxes, either of the wooden or plastic designs. The highest daily pre-treatment consumption of census bait was $2.20 \mathrm{~kg}$ and the highest daily track score was 55 (Table 5).

\begin{tabular}{|c|c|c|c|c|c|c|c|c|}
\hline Site & $\begin{array}{c}\text { Total pre- } \\
\text { treatment } \\
\text { census bait } \\
\text { take }\left(\mathrm{kg}^{-1}\right)\end{array}$ & $\begin{array}{c}\text { Highest daily } \\
\text { pre- } \\
\text { treatment } \\
\text { census bait } \\
\text { take }\left(\mathrm{kg}^{-1}\right)\end{array}$ & $\begin{array}{c}\text { Total pre- } \\
\text { treatment } \\
\text { track score }\end{array}$ & $\begin{array}{c}\text { Highest daily } \\
\text { pre- } \\
\text { treatment } \\
\text { track score }\end{array}$ & $\begin{array}{c}\text { Total post- } \\
\text { treatment } \\
\text { census bait } \\
\text { take }\left(\mathrm{kg}^{-1}\right)\end{array}$ & $\begin{array}{c}\text { Highest daily } \\
\text { post- } \\
\text { treatment } \\
\text { census bait } \\
\text { take }\left(\mathrm{kg}^{-1}\right)\end{array}$ & $\begin{array}{c}\text { Total post- } \\
\text { treatment } \\
\text { track score }\end{array}$ & $\begin{array}{c}\text { Highest daily } \\
\text { post- } \\
\text { treatment } \\
\text { track score }\end{array}$ \\
\hline
\end{tabular}




\begin{tabular}{|l|c|c|c|c|c|c|c|c|}
\hline $1^{*}$ & 6.87 & 2.20 & 242 & 55 & 7.89 & 1.86 & 286 & 58 \\
\hline 2 & 33.36 & 10.57 & 418 & 115 & 13.20 & 4.20 & 169 & 45 \\
\hline 3 & 9.20 & 2.73 & 154 & 43 & 2.83 & 0.92 & 94 & 27 \\
\hline 4 & 15.07 & 5.49 & 285 & 84 & 17.80 & 5.57 & 323 & 0.01 \\
\hline 5 & 4.88 & 1.37 & 172 & 50 & 0.02 & 0 & 0.03 & 4 \\
\hline 6 & 9.78 & 3.18 & 336 & 96 & 0.05 & 0. & 3 \\
\hline
\end{tabular}

Table 5. Results of pre- and post-treatment census baiting and tracking at the six experimental sites.

361 If certain assumptions are made about the rat infestation, it is possible to estimate the number of individuals present at the site from the quantity of census bait consumed. These assumptions are: 1) rats consume only census bait during the baiting period, 2) rats have a mean weight of $200 \mathrm{~g}, 3$ ) Norway rats consume $10 \%$ of their body weight in dry food each day. These assumptions, and the maximum daily census bait take of $2.20 \mathrm{~kg}$, result in an estimated population size of 110 rats. Such estimates are conservative as it is very unlikely, given the known neophobia of Norway rats and the presence of abundant alternative food sources at trial sites, the rats fed exclusively from the census bait (Barnett, 1958; Inglis et al., 1996).

The $50 \mathrm{ppm}$ difenacoum pellet poisoned bait was applied according to the manufacturer's label instructions, following a lag period. Once again, initial takes of this bait were poor, and certainly less than might have been expected from the apparent size of the infestation, although they showed a steady increase over the first 20 days of the treatment. Thereafter, and until the treatment was terminated after 48 days of baiting, takes of poisoned bait fluctuated between replenishment visits from approximately $2 \mathrm{~kg}$ to $3 \mathrm{~kg}$ (Fig. 1). During the treatment period, track scores fluctuated between 37 and 61, but it should be noted that these scores are not directly comparable with the daily track scores recorded during the pre-treatment period because they are the accumulate track score for either three or four days.

The post-treatment was conducted after a lag period of six days and the maximum daily take of census bait $(1.86 \mathrm{~kg})$ was recorded on the last of the six days of census baiting. The maximum daily track score, also recorded on the sixth day, was 58 (Table 5). 


\begin{tabular}{|c|c|c|c|c|c|c|}
\hline \multirow[t]{2}{*}{ Site } & \multirow[t]{2}{*}{$\begin{array}{l}\text { Active substance } \\
\text { (conc. ppm) }\end{array}$} & \multirow{2}{*}{$\begin{array}{l}\text { Maximum daily } \\
\text { take of pre- } \\
\text { treatment census } \\
\quad \text { bait }(\mathrm{kg})^{\S}\end{array}$} & \multirow{2}{*}{$\begin{array}{l}\text { Total } \\
\text { quantity of } \\
\text { rodenticide } \\
\text { used }(\mathrm{kg})\end{array}$} & \multirow{2}{*}{$\begin{array}{c}\text { Total quantity } \\
\text { of active } \\
\text { substance } \\
\text { applied (g) }\end{array}$} & \multicolumn{2}{|c|}{$\begin{array}{l}\text { Estimated mortality } \\
(\%)^{*}\end{array}$} \\
\hline & & & & & $\begin{array}{l}\text { Census } \\
\text { baiting }\end{array}$ & $\begin{array}{l}\text { Track } \\
\text { Score }\end{array}$ \\
\hline 1 & difenacoum (50ppm) & $2.20(110)$ & 28.57 & 1.43 & 15.5 & +5.5 \\
\hline 2 & difenacoum (50ppm) & $10.57(529)$ & 59.24 & 2.96 & 60.3 & 60.9 \\
\hline 3 & bromadiolone (50 ppm) & $2.73(136)$ & 17.67 & 0.88 & 66.3 & 37.2 \\
\hline 4 & bromadiolone (50 ppm) & $5.49(275)$ & 43.19 & 2.16 & +1.5 & +3.6 \\
\hline 5 & brodifacoum (23 ppm) & $1.37(69)$ & 4.38 & 0.10 & 99.3 & 100.0 \\
\hline 6 & brodifacoum (23 ppm) & $3.18(159)$ & $9.68+$ & 0.22 & 98.4 & 96.9 \\
\hline
\end{tabular}

Notes: ${ }^{\S}$ values in brackets are the estimated numbers of rats present at the start of the treatments (assumptions are given in the text)

* mortality estimates preceded by + indicate estimated population growth during treatment

+ includes burrow bait that was applied but some of which was probably not consumed

Table 6. The results of efficacy assessments conducted at the six trial sites. The maximum daily pre-

treatment census bait take is shown as an indirect measure of the sizes of the initial infestations.

Initial takes of census bait at site 2 were high, indicating that the rat infestation exhibited little or none of the bait shyness that had been seen at site 1 (Fig. 1). This was in spite of abundant alternative food at the site (section 2.1). Similarly, the rats readily entered the wooden bait boxes used from the first day of the census. These observations demonstrated that differences in the behaviour of the field infestations may influence both treatment durations and treatment outcomes. A total of $33.36 \mathrm{~kg}$ of census bait was consumed over four days of the pre-treatment census baiting, with a maximum daily take of $10.57 \mathrm{~kg}$. The total track score for the four days was 169 , with a 
The takes by rats of difenacoum pellets at site 2 were also initially high, as might be expected from a large infestation showing little or no reluctance to take apparently highly palatable bait. For example $9.96 \mathrm{~kg}$ of bait were eaten over the first five days of baiting. Bait takes declined over the following 14 days (Fig. 1) and thereafter continued at a fairly constant rate for a period of about three weeks. This pattern of bait take may occur when a resistant infestation is treated with a resisted anticoagulant. The more susceptible animals succumb to the bait initially, particularly when bait takes are good, leaving only the more resistant animals remaining to continue feeding. It is this process which increases the incidence of resistance mutations within resistant populations, as well as the severity of resistance. After 35 days of baiting, it became apparent both from the quantities of poisoned bait taken and the track score (Fig. 1) that little further progress would be made and the treatment was discontinued.

The post-treatment census began, following a four-day lag period, but a very heavy fall of snow overnight prevented access to the farm on the third day of the census and for seven days thereafter. Eventually, the census bait was removed and a second, five-day lag period was applied before the census bait procedure began again. Overall, 19 days separated the removal of the poisoned bait and the commencement of the second census period. Given the extremely cold weather and the deeplaying snow, it seems unlikely that the rat infestation remaining on the farm was significantly supplemented by either immigration or breeding.

The results of this census are shown in Fig. 1 . The maximum census bait take $(4.20 \mathrm{~kg})$ was recorded on the fourth night of the census and the maximum track score of 45 was recorded on the third night. These data were used to obtain estimates of rat mortality achieved by the treatment of $60.3 \%$, using census baiting, and $60.9 \%$ using track scores. 
421 The Norway rats at this site apparently took the census bait without reluctance and there were good

422 takes across the entire area. The maximum daily census bait consumption, $2.73 \mathrm{~kg}$, was recorded on

423 the fourth night of the census but the takes for the two preceding nights were not much less (Fig. 1).

424 The maximum track score was 43 on the second night of the census. The census bait take was used

425 to estimate the rat infestation at 136 rats, making as before the somewhat unlikely assumption that

426 the rats only ate census bait. Takes of poisoned bait were initially good and a total of $6.80 \mathrm{~kg}$ of

427 bromadiolone bait was consumed during days four to seven of the application. However, bait takes fell rapidly thereafter and continued at a regular, but considerably, lower level for the remaining period of the treatment. After 35 days of poisoned baiting it became apparent, from the continuing 430 low level takes of poisoned bait and track score, that little further reduction of the infestation would be achieved and the treatment was therefore terminated.

The post-treatment census monitoring was initiated and was conducted in the same way as the pretreatment census, using the same tracking patch and bait point locations. The four-day posttreatment tracking patch census was assessed daily, and produced a total census score of 94 and a maximum on day four of the census of 27 (Fig. 1). The post-treatment census bait consumption was measured daily for four days, and resulted in a total bait take of $2.83 \mathrm{~kg}$, with a maximum take of

$437 \quad 0.92 \mathrm{~kg}$ on the third day of the census (Table 5). These records provided estimates of the percentage mortality of rats at the site caused by the bromadiolone treatment of $66.3 \%$ using census baiting and $37.2 \%$ using the track score values. There was no obvious explanation for the difference between these two values but it is usually considered that mortality estimates derived from census bait data are more reliable than those obtained from track scores. four-day census period. Consumption was good on the first day of baiting, when the rats consumed 
the census (Table 5). It seems likely that census bait take would have continued to rise had the census continued for a longer period. The number of rats present at the site was conservatively estimated, from census bait consumption, to be 275 individuals. The total track score during the four-day census was 285 , with a maximum of 84 on the fourth day of the census.

Takes of bromadiolone bait were initially high, with a total of $7.67 \mathrm{~kg}$ of bait consumed during the first four days of the treatment (Fig. 1). The average daily consumption of $1.92 \mathrm{~kg}$ was, however, less than the average daily consumption of census bait of $3.75 \mathrm{~kg}$. During the period of poisoned baiting a pattern was observed in which consumption of bait remained high but showed a steady decline. Given the high quantities of bait consumed, it is likely that some rats would have died during this period, resulting in the observed decrease in both bait take and track score (Fig. 1). However, total bait takes were $7.57 \mathrm{~kg}$ and $5.12 \mathrm{~kg}$ respectively in the fourth and fifth weeks of the treatment and track scores showed an increase. The decision was therefore made to terminate the treatment after 35 days of poisoned baiting and a total consumption by the rats at the site of $43.19 \mathrm{~kg}$ of bromadiolone bait (Table 6).

The work at site 4 was carried out synchronously with that nearby on site 2 and the post-treatment census period was similarly disrupted by a very heavy fall of snow. When the post-treatment census was carried out it resulted in a maximum daily take of census bait of $5.57 \mathrm{~kg}$ and a maximum daily track score of 87 (Table 5). When these values were used to assess the effectiveness of the bromadiolone treatment, both resulted in an estimated growth of the infestation, of $1.5 \%$ and $3.6 \%$ for census baiting and track score respectively (Table 6).

The infestation at this site was apparently the smallest of those present among the six trial sites. A total of $4.88 \mathrm{~kg}$ of census was consumed over four days, with the maximum $1.37 \mathrm{~kg}$ taken on the fourth day. This value provides a conservative estimate of 69 rats at the site. The nature of the site, 
the fact that the activity of the infestation was mainly focussed outdoors and the frequent rain that occurred during the trial, made it difficult to establish tracking patch points that remained dry and capable of recording rat foot-prints throughout the census. However, a total track score of 172 was recorded, with a maximum daily score of 50 on the fourth day of the census.

The consumption of the brodifacoum wax blocks was initially poor, with only $210 \mathrm{~g}$ of bait eaten in the first two days of baiting. This may have been due either to the initial inability of the rats to recognise the blocks as food or, if they were recognised as food, a reluctance to consume them. However, bait takes then increased and reached a maximum at the end of the first week of baiting, when more than a kilogramme of bait was consumed over three days (Fig. 1). Thereafter, bait takes declined quickly, as did the tracking score, indicating that the rat infestation was being quickly extinguished. After three weeks of baiting, both bait takes and track score had reached very low levels. Unfortunately, at this time field signs at some bait stations indicated that a portion of the continuing activity observed may have been due to grey squirrels (Sciurus carolinensis). Camera traps were deployed and confirmed that this was the case. Grey squirrels are, of course, non-target animals in the context of outdoor baiting with anticoagulants and, therefore, bait was immediately removed from the site and the trial paused. Five squirrels were subsequently humanely trapped and removed from the site and the trial resumed. The duration of the pause was 24 days, but baiting continued thereafter for a further 18 days, until both track scores and bait takes were reduced to zero. Bait takes from stations that are considered likely to have been visited by squirrels were subtracted from the estimated total consumption of poisoned bait.

As in previous trials, the post-treatment census was carried out in the same way as the pretreatment census. No activity was detected on any tracking patches, giving an estimate of mortality by that method of $100 \%$. However, there were several very small takes of census bait, amounting to a total of $21 \mathrm{~g}$ over the four-day census period. Although it was likely that these takes were by either wood mice (Apodemus sylvaticus) or bank voles (Myodes glareolus), it was not possible from 
the field signs entirely to dismiss the likelihood that they were small rat takes. Therefore, the estimate of mortality brought about by the application of $23 \mathrm{ppm}$ brodifacoum wax blocks at site 5 , using census baiting, was estimated to be $99.3 \%$.

Site 6. Small mixed farm, nr. Basingstoke, Hampshire

Rats at site 6 ate more than $1.5 \mathrm{~kg}$ of wheat bait on the first day of census baiting, indicating that they were not reluctant to take a novel foodstuff. Bait takes increase daily until, on the last day of census baiting, the take of bait reached $3.18 \mathrm{~kg}$, with a total consumption over the four days of baiting of $9.78 \mathrm{~kg}$. The daily bait take provides, using the same assumptions as before, an estimate of 159 rats. The maximum track score during the pre-treatment census was 96.

Takes of the $23 \mathrm{ppm}$ brodifacoum pellet bait were initially very good, with a total take of more than $2.5 \mathrm{~kg}$ over the first three days of baiting. Thereafter, takes of bait declined quickly during the following two weeks (Fig. 1). However, although the track score also showed a decline, its degree did not match that seen in the poisoned bait take data. About three weeks into the treatment it became apparent that rats remained active at the site but they were not taking the poisoned bait. Any open rat burrows seen were blocked and it was found that a considerable number of rat burrows remained active around an outdoor pen where poultry was kept and fed ad libitum. A normal procedure in this case during a conventional treatment would be to employ burrow baiting, in an attempt to induce the rats to take bait. However, although it is possible to record the quantity of bait put out in burrow baiting, it is not possible to estimate bait consumption, as is desirable in a monitored rodenticide trial. Therefore, conventional baiting continued for another week in the hope that the infestation could be extinguished. When this did not occur, burrow baiting was first employed on day 30 of the application. A total of 41 burrows were treated with $50 \mathrm{~g}$ of pellets each and burrows which remained active between treatment visits were baited until day 43 of the treatment. These burrow baits were included in the calculations of the quantities of bait applied but it seems likely that at least some of this bait was not consumed by rats. 
520 The post-treatment census began after a five-day lag period. Census bait take was observed on two

521 of the four census days, with a maximum of $32 \mathrm{~g}$ of bait eaten on the fourth and final day. Similarly

522 tracking activity was observed on two days, with a maximum score of 3 on the first day of the

523 census. Once again, it was impossible from the field signs to preclude the possibility that these takes

524 were by rats and, therefore, these data provide estimates of mortality of $98.4 \%$ and $96.9 \%$, using

525 census bait takes and track scores respectively.

526 It is generally considered that effective anticoagulants should control a rat infestation that is

527 susceptible to it within about 35 days (EC, 2011). The treatment at site six continued for a week

528 longer than this but it is probable that the treatment would have ended earlier had burrow baiting

529 been applied more expeditiously. 

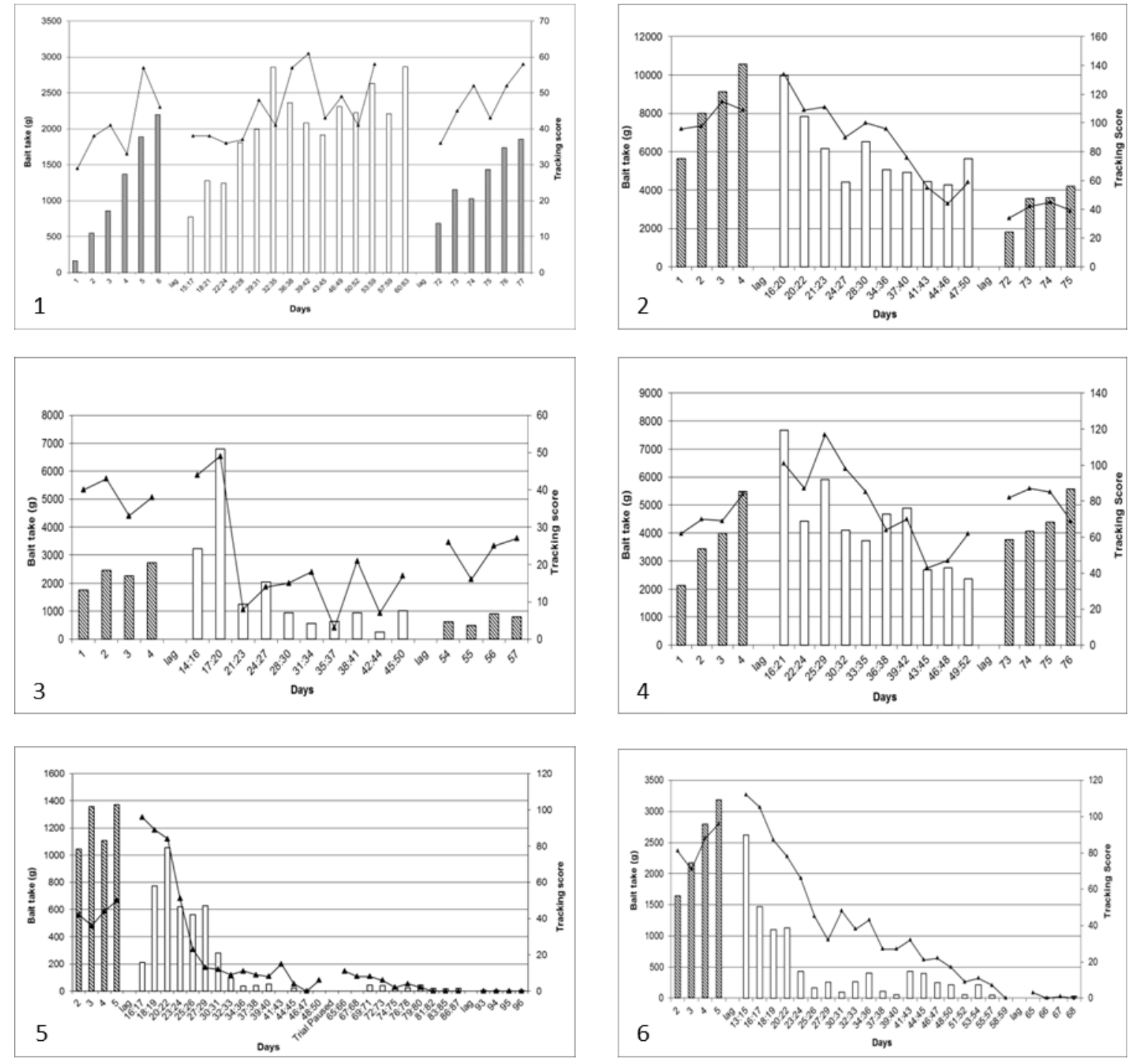

Figure 1. Summary of the progression of six anticoagulant field trials conducted at farmsteads in

Berkshire and Hampshire, UK. Sites 1 and 2, $50 \mathrm{ppm}$ difenacoum commercial pellet bait; sites 3 and

4, 50 ppm bromadiolone commercial pellet bait; site 5, 23 ppm brodifacoum experimental wax block formulation; site 6, 23 ppm commercial brodifacoum pellet bait. Hatched bars, census bait takes; open bars, poisoned bait takes; line, tracking score. Note: track scores are for a 24 -hour period during the pre- and post-treatment census, during the poisoned baiting they are aggregate scores for two- to three-day periods. A six-day census period was employed at site 1 because of the initial reluctance of rats to take census bait. The post-treatment lag period was prolonged at sites 2 and 4 because of heavy snowfall. 
541 The application of anticoagulant rodenticides is the principle management intervention applied in

542 almost all rodent pest scenarios worldwide, in both crop protection and public health (Jacob and

543 Buckle, 2018). No alternatives exist that are sufficiently effective (ECHA, 2017b) and possess similar

544 safety features, including a specific antidote (vitamin $\mathrm{K}_{1}$ ) and a slow mode of action which provides

545 time for its administration (Buckle and Eason, 2015). There is little evidence of technology capable

546 of fully replacing anticoagulants becoming available in the foreseeable future (Buckle and Smith,

547 2015). However, anticoagulant resistance is a significant threat to the continued effective use of

548 these active substances (Berny et al., 2018 ) and resistance management strategies are required to

549 extend the useful lives of these essential products (RRAC, 2020).

550 Research in the Hampshire and Berkshire area, over many years and using different resistance

551 monitoring techniques, has shown the prevalent nature of the L120Q resistance SNP in the area of

552 this study (Buckle, 2013; Jones et al., 2019). The interactive resistance maps provided by the

553 Rodenticide Resistance Action Committee of CropLife International (available here:

554 http://guide.rrac.info/mapas-de-resistencia/reino-unido/?L=3\%27A), based on DNA testing

555 conducted at the University of Reading, demonstrate the known scale and geographical scope of the

556 resistance focus. Therefore, it was unsurprising that the rats on six Hampshire/Berkshire farms were

557 found to carry the L120Q SNP. What was surprising, however, was the very high incidence of

558 resistance; with only one susceptible animal found in a sample of 107 rats from the trial sites, and

559 the high incidence of homozygosity (86.9\%). These results indicate prolonged selection pressure

560 towards resistance exerted by the application, over a period of more than 30 years, of only partially-

561 effective rodenticides. The late J.H. Greaves wrote, "the unabated use of anticoagulants to which

562 resistance has developed will unremittingly cause resistance to these compounds to spread"

563 (Greaves, 1994). Apparently this lesson was not learned and the consequences for resistance of a

564 regulatory policy that, effectively, enforced the prolonged use of resisted active substances, is

565 apparent (Jones et al., 2019). Also, the relatively high initial numbers of rats on the trial farms (Table

566 6) were not unusual at this resistance focus, in spite of almost continual but ineffectual attempts to 
control them with bromadiolone and difenacoum baits (Quy et al., 1995), and by other physical means such as trapping, dogs and shooting.

It is also clear from the foregoing that none of the six field trials described here progressed in an entirely predicted manner. Rats appeared to be unusually reluctant to take bait at one site. This may have resulted in an underestimate of the initial size of the infestation during census baiting, in turn leading to an over-estimate of treatment efficacy. However, poor poisoned bait uptake and its consequential detrimental effect on treatment efficacy would have exerted possible bias in the opposite direction. Heavy snowfall caused the work of the post-treatment census to be unavoidably abandoned and resumed later at two trial sites. There is a possibility that this prolonged, unscheduled lag period may have permitted some rats to repopulate the sites, but the extreme winter weather conditions, very low temperatures and deep-laying snow, would have militated against this to a considerable extent. On another site the treatment was interrupted when it was found, almost at the end of the treatment, that non-target grey squirrels were entering bait boxes and taking poisoned bait. The trial could have been terminated at that point because very few rats apparently remained. However, it was decided to pause the work, remove the squirrels, and then continue in an attempt to extinguish the infestation. This resulted in a necessarily prolonged trial. Finally, poor bait takes, probably due to the proximity of palatable alternative food, and justifiable reluctance on the part of the researchers to employ burrow baiting because of the difficulty this presented in quantifying bait takes, resulted in another prolonged treatment at site 6; although virtually complete control was eventually achieved.

In spite of these experimental difficulties, a consistent pattern emerges from this study on the field efficacy of anticoagulants against Hampshire/Berkshire L120Q rats. The four 50 ppm difenacoum and bromadiolone treatments were substantially ineffective and the two applications of baits carrying 23 ppm brodifacoum were both highly effective. The current regulatory authorisation requirement for proof of efficacy of a rodenticide is $90 \%$ mortality in field trials (ECHA, 2017a), and it 
is clear that all the difenacoum and bromadiolone treatments failed this criterion by wide margins.

593

594

595

596

597

598

599

600

601

602

603

604

605

606

607

608

609

610

611

612

613

614

615

616

Previously, bromadiolone had performed consistently better than difenacoum against Norway rats in the Hampshire resistance focus (Greaves et al., 1982b) but this was not seen in the present study. The resistance factors calculated here, using blood-clotting response tests conducted in 2009-10, confirmed a shift towards a higher degree of resistance than those observed previously (Greaves and Cullen-Ayres, 1988). However, if the advanced 'Berkshire' phenotype had entirely replaced the once-prevalent, and more susceptible, 'Hampshire' phenotype at all the trial sites, we might have expected both compounds to perform consistently poorly where they were applied. This was not the case, as at one site where each substance was used they provided a similar, partial degree of control; difenacoum, 60.3-60.9\% mortality on site 2 and bromadiolone $37.2-66.3 \%$ mortality on site

3. However, at the other sites where bromadiolone and difenacoum were used the outcomes were similar in their degree of complete failure to that seen for bromadiolone in a field trial conducted many years earlier (Quy et al., 1995). It seems likely, therefore, that at some sites other factors, in addition to anticoagulant resistance, may have influenced the outcomes of treatments, possibly the unwillingness of the rat infestations to take the commercial baits (Cowan et al., 1995). Whatever the causes of the variable effectiveness of the two less-potent anticoagulants, it is clearly apparent that they should not be recommended for Norway rat control where the L120Q resistance mutation is prevalent (RRAG, 2018).

Evidence has been growing for the past thirty years of widespread contamination of UK wildlife with SGARs (Shore et al., 2015). The list of exposed species is extensive and includes, among others, barn owl (Tyto alba), red kite (Milvus milvus), buzzard (Buteo buteo), kestrel (Falco tinnunculus), stoat (Mustela erminea), weasel (Mustela nivalis), polecat (Mustela putorius), fox (Vulpes vulpes) and hedgehog (Erinaceus europaeus). One of the few positive notes to emerge from this, however, is that there is currently no evidence that any exposed species has declined as a result of this exposure (Smith and Shore, 2015). Indeed, some of the most exposed populations of birds (i.e. red kite, barn 
owl and buzzard) are rapidly increasing, both in numbers and in their geographical distribution across the UK (Harris et al., 2019).

In simple terms, the risk of non-target effects of rodenticide applications is a function of the intrinsic toxicity of the active substance to exposed species, the quantity applied and the duration of its availability in the environment (Newton, 2018). In turn, the quantities applied are influenced by concentration of the active substance in the bait, the application rates (determined by the product label) and the size and scope of the treated rodent infestation. Actual impacts are affected by the degree of risk of any non-target species' exposure and the effectiveness of the risk mitigation measures employed when using these substances (Buckle and Prescott, 2018; López-Perea and Mateo, 2018; Shore and Coerdassier, 2018). Table 6 shows the quantities of active substance released to the environment during SGAR applications reported here. These ranged from $0.10 \mathrm{~g}$ to $2.96 \mathrm{~g}$ of active substance per treatment; one almost thirty times the other. Unsurprisingly, the unsuccessful bromadiolone and difenacoum treatments resulted in much larger emissions than the more successful brodifacoum treatments. This was because smaller quantities of brodifacoum baits were applied (i.e. pulsed baiting, see Buckle and Eason, 2015), the baits contained lower concentrations of the active substance ( $23 \mathrm{ppm}$ instead of $50 \mathrm{ppm})$ and the duration of feeding on brodifacoum baits by the treated rat infestations was shorter (Fig. 1). The most significant period of risk of secondary exposure of predators during anticoagulant treatments is likely to be during the 'latency period'; that is after consumption of bait by target animals and before their deaths (Buckle and Prescott, 2018). During this time the animals remain active in the environment, continue to consume rodenticide and exhibit normal behaviour until, latterly, showing some reduced sensory and motor function, and abnormal behaviours, due to poisoning (Cox and Smith, 1992). When a lethal dose of an anticoagulant is taken, this latency period may be quite short, usually only 3-5 days and rarely longer than ten (Buckle and Eason, 2015). However, in the unsuccessful difenacoum and bromadiolone treatments recorded here, the latency period is very much longer, in effect the entire 
lives of these substances (Horak et al., 2018). A scenario therefore emerges in this part of the UK where the L120Q SNP is widespread, and where difenacoum and bromadiolone continue to be used extensively, that a high proportion of individuals within extant Norway rat infestations carry SGAR residues that are virtually continuously available for ingestion by non-target animals through predation and scavenging. This occurrence in Hampshire and Berkshire, and probably to a lesser extent in other resistance foci (Jones et al., 2019), may go some way to explain the widespread nature of anticoagulant residues in predatory birds and mammals, particularly of bromadiolone and difenacoum (Shore et al., 2019). In the brodifacoum treatments, the relatively smaller quantities of active substance emitted resulted in the virtual extirpation of the rat infestations (Table 6) and, therefore, both to a lower overall SGAR emission and shorter duration of potential secondary exposure of predators. uses of the second-generation anticoagulants. Firstly, as mentioned above, the more potent anticoagulants, brodifacoum, difethialone and flocoumafen, have been authorised for use outdoors. This has made available, for the first time, potentially highly-effective resistance-breaking active substances for use in resistance foci, such as that of Norway rat L120Q resistance studied here. However, to accompany this change, a programme of rodenticide stewardship has been introduced which has brought about important changes in whom can purchase SGARs and how they can be used (Buckle et al., 2017). UK Government assessment of the stewardship regime will determine future rodenticide regulation and permitted use practices and, in so doing, will continue to affect the development and spread of anticoagulant resistance and the prevalence of anticoagulant residues in UK wildlife (GOG, 2019). However, so far no significant increase in total SGAR residues has been detected in the chosen sentinel species, barn owl, as a result of the regulatory change which 
The authors are grateful to $\operatorname{Dr} A$ Cornish for his support and guidance during the study. The work was funded by Syngenta AG, Basel, Switzerland.

\section{REFERENCES}

Atterby, H., Kerins, G.M. and Macnicoll, A.D. (2005) Whole-carcass residues of the rodenticide difenacoum in anticoagulant-resistant and-susceptible rat (Rattus norvegicus). Environ. Toxicol. Chem. 24:318-323.

Barnett, S.A. (1958) Experiments on "neophobia" in wild and laboratory rats. Br. J. Psychol. 49:195201.

Berny, P., Esther, A., Jacob, J. and Prescott, P. (2018) Development of resistance to anticoagulant rodenticides in rodents, Chapter 10 in Anticoagulant Rodenticides and Wildlife, eds. van den Brink, N.W., Elliott, J.E., Shore, R.F. and Rattner, B.A. Springer International Publishing AG, Cham, Switzerland. pp 259-286.

Boitet, M., Hammed, A., Chatron, N., Debaux, J.V., Benoit, E. and Lattard, V. (2018) Elevated difenacoum metabolism involved in the difenacoum-resistant phenotype observed in Berkshire rats homozygous for the L120Q mutation in Vkorc1 gene. Pest Manage. Sci. 74:1328-1334.

Buckle, A.P. (2013) Anticoagulant resistance in the UK and a new guideline for the management of resistant infestations of Norway rats (Rattus norvegicus Berk.) Pest Manage. Sci. 69:334-341.

Buckle, A.P. and Prescott, C.V. (2011) Effects of tamper-resistant bait boxes on bait uptake by Norway rats (Rattus norvegicus Berk.) Int. J. Pest Manage. 57:77-83.

Buckle, A.P. and Eason, C.T. (2015) Control methods: chemical. Chapter 6 in Rodent Pests and their Control, 2nd Edition, eds. Buckle, A.P.and Smith, R.H. CAB International, Wallingford, Oxon, UK. pp 123-154.

Buckle, A.P. and Smith, R.H. (2015) Rodent control: Back to the future (the sequel). Chapter 19 in Rodent Pests and their Control, 2nd Edition, eds. Buckle, A.P. and Smith, R.H. CAB International, Wallingford, Oxon, UK. pp 397-402. 

[accessed 29 August 2017]. resistance on the use of second-generation anticoagulants against rats on farms in Southern England. Pestic. Sci. 43, 83-93.

Cox, P. and Smith, R.H. (1992) Rodenticide ecotoxicology:pre-lethal effects of anticoagulants on rat behaviour. In Proceedings 15th Vertebrate Pest Conference, ed by Borrecco, J.E. and Marsh, R.E. Newport Beach, California, 3-5 March, pp. 165-170. of anticoagulant rodenticides - a modelling approach. Book of Abstracts. Eighth European Vertebrate Pest Management Conference, Berlin, Julius Kuhn Institute and Humboldt University, Berlin, ed. by Jacob, J. and Esther, A. pp 58-59. EC. (2011) Technical Notes for Guidance Efficacy Evaluation of Rodenticides (Product Type 14) Product Evaluation.. Document endorsed at the 32nd meeting of representatives of Members States

716 Competent Authorities for the implementation of Directive 98/8/EC concerning the placing of biocidal products on the market (18-20 February 2009), European Commission, Brussels. 22 pp. 
ECHA. (2017a) Guidance on the Biocidal Products Regulation Volume II Efficacy - Assessment and Evaluation (Parts B+C) Version 2.0. European Chemicals Agency, P.O. Box 400, FI-00121 Helsinki, Finland. ISBN: 978-92-9020-259-2. Dol: 10.2823/532500. December 2017, pp 168-182.

ECHA. (2017b) Opinion on a request according to Article 75(1)(g) of Regulation (EU) No 528/2012 on Questions regarding the comparative assessment of anticoagulant rodenticides. European Chemicals Agency, Helsinki, Finland. ECHA/BPC/145/2017. 15 pp.

Endepols, S.E., Klemann, N., Jacob, J. and Buckle. A.P. (2011) Resistance tests and field trials with bromadiolone for the control of Norway rats (Rattus norvegicus) on farms in Westphalia, Germany. Pest Manage. Sci. 68(3):348-354.

EPPO. (1998) Efficacy evaluation of rodenticides Field Tests against Synanthropic Rodents (Mus musculus, Rattus norvegicus, R. rattus). European and Mediterranean Plant Protection Organization Organisation/Européenne et Méditerranéenne pour la Protection des Plantes (EPPO) PP 1/114(2):36-47 (1998).

Gill, J.E. and MacNicoll, A.D. (1991) Determination of the susceptibility of wild populations of the Norway rat (Rattus norvegicus) to the anticoagulant brodifacoum. Zeitschrift für angewandte Zoologie 78:101-117.

Gill, J.E., Kerins, G.M. and MacNicoll, A.D. (1992) Inheritance of low grade brodifacoum resistance in the Norway rat. J. Wildl. Manage. 56:809-816.

Greaves, J.H. (1994) Resistance to anticoagulant rodenticides, Chapter 17 in Rodent Pests and their Control, $1^{\text {st }}$ ed., ed. by Buckle, A.P. and Smith, R.H. CAB International, Wallingford, Oxon, UK. pp 197-217.

Greaves, J.H. and Rennison, B.D. (1973) Population aspects of warfarin resistance in the Brown rat, Rattus norvegicus. Mammal Review 3:27-29.

Greaves, J.H., Shepherd, D.S. and Gill, J.E. (1982a) An investigation of difenacoum resistance in Norway rat populations in Hampshire. Ann. Appl. Biol. 100: 581-587. 
Greaves, J.H., Shepherd, D.S. and Quy, R.J. (1982b) Field trials of second-generation anticoagulants against difenacoum-resistant Norway rat populations. J. Hyg., Camb. 89:295-301. Greaves, J.H. and Cullen-Ayres, P.B. (1988) Genetics of difenacoum resistance in the rat, in Current Advances in Vitamin K Research ed. by Suttie, J.W. Elsevier Amsterdam, pp 389-397.

GOG. (2019 An information paper by the Rodenticides Stewardship Regime Government Oversight 2019, 11 pp. Available at: http://www.hse.gov.uk/biocides/eu-bpr/rodenticides.htm [accessed 3 December 2019]. Harris, S.J., Massimino, D., Eaton, M.A., Gillings, S., Noble, D.G., Balmer, D.E., Pearce-Higgins, J.W. and Woodcock, P. (2019) Breeding Bird Survey 2018, BTO Research Report 717, British Trust for Ornithology, Thetford, UK, $36 \mathrm{pp}$. Horak, K.E., Fisher, P.M. and Hopkins, B. (2018) Pharmacokinetics of anticoagulant rodenticides in target and non-target organisms. Chapter 4 in Anticoagulant Rodenticides and Wildlife, eds. van den Brink, N.W., Elliott, J.E., Shore, R.F. and Rattner, B.A. eds. Springer International Publishing AG, Cham, Switzerland. pp 87-108. HSE. (2012) Environmental risk mitigation measures for second generation anticoagulant rodenticides proposed by the UK. Chemicals Regulation Directorate, Health and Safety Executive, UK, August 2012. 30 pp. Foraging behaviour of wild rats (Rattus norvegicus) towards new foods and bait containers. Applied Animal Behaviour Science 47:175-190. Jacob, J. and Buckle, A.P. (2018) Use of anticoagulant rodenticides in different applications around the world, Chapter 2 in Anticoagulant Rodenticides and Wildlife, eds. van den Brink, N.W., Elliott, J.E., Shore, R.F. and Rattner, B.A. Springer International Publishing AG, Cham, Switzerland. pp 11-43. Jones, C., Talavera, M., Buckle, A. and Prescott, C. (2019) Anticoagulant Resistance in Rats and Mice in the UK - Summary Report with new data for 2019, Report from the Campaign for Responsible 
Rodenticide Use (CRRU) UK for the Government Oversight Group. Vertebrate Pests Unit, The University of Reading. Report no. VPU/19/012. 17 pp. https://www.thinkwildlife.org/downloads/ [accessed 18 November 2019].

Kaukeinen, D.E. and Buckle, A.P. (1992) Evaluations of aversive agents to increase the selectivity of rodenticides, with emphasis on denatonium benzoate (Bitrex) bittering agent. In Proceedings 15th Vertebrate Pest Conference, ed by Borrecco, J.E. and Marsh, R.E. Newport Beach, California, 3-5 March, pp. 192-198.

López-Perea, J.J. and Mateo, R. (2018) Secondary exposure to anticoagulant rodenticides and effects on predators, Chapter 7 in Anticoagulant Rodenticides and Wildlifel, eds. van den Brink, N.W., Elliott, J.E., Shore, R.F. and Rattner, B.A. Springer International Publishing AG, Cham, Switzerland pp 159-193.

Markussen, M.D.K., Heiburg, A-C., Nielsen, R. and Leirs, H. (2008) Differential expression of cytochrome P450 genes between bromadiolone-resistant and anticoagulant-susceptible Norway rats: a possible role for pharmacokinetics in bromadiolone resistance. Pest. Manage. Sci. 64: 239248.

Newton, I. (2018) Foreword. In Anticoagulant Rodenticides and Wildlife, eds. van den Brink, N.W., Elliott, J.E., Shore, R.F. and Rattner, B.A. Springer International Publishing AG, Cham, Switzerland. pp v-viii (2018).

Pelz, H-J., Rost, S., Hünerberg, M., Fregin, A., Heiberg, A-C., Baert, K., MacNicoll, A.D., Prescott, C.V., Walker, A-S., Oldenburg, J. and Müller, C.R. (2005) The genetic basis of resistance to anticoagulants in rodents. Genetics 170:1839-1847.

Pelz, H-J. and Prescott, C.V. (2015) Resistance to anticoagulant rodenticides, in Rodent Pests and their Control, 2nd Edition, Buckle, A.P. and Smith, R.H. eds. CAB International, Wallingford, Oxon, UK, pp 187-208.

Prescott, C.V., Buckle, A.P. and Endepols, S. (2007) A standardised BCR resistance test for all anticoagulant rodenticides. Int. J. Pest Manag. 53:265-272. 
795

796

797

798

799

800

801

802

803

804

805

806

807

808

809

810

811

812

813

814

815

816

817

818

819

Quy, R.J., Shepherd, D.S. and Inglis, I.R. (1992) Bait avoidance and the effectiveness of anticoagulant rodenticides against warfarin- and difenacoum-resistant populations of Norway rats (Rattus norvegicus). Crop Prot. 11: 13-19.

Quy, R.J., Cowan, D.P. and Swinney, T. (1993) Tracking as an activity index to measure gross changes in Norway rat populations. Wildlife Society Bulletin 21:122-127 (1993).

Quy, R.J., Cowan, D.P., Prescott, C.V., Gill, J.E., Kerins, G.M., Dunsford, G., Jones, A. and Macnicoll, A.D. (1995) Control of a population of Norway Rats resistant to anticoagulant rodenticides. Pestic. Sci. 45:247-256.

Refern, R. and Gill, J.E. (1978) The development and use of a test to identify resistance to the anticoagulant difenacoum in the Norway rat (Rattus norvegicus). J. Hyg., Camb. 81:427-431. RRAC. (2020) RRAC Resistance Guide. Rodenticide Resistance Action Committee, Croplife International, Brussels, Belgium. Interactive web-based document. https://guide.rrac.info/aim-andauthors.html [accessed 10 March 2020].

RRAG. (2018). Anticoagulant resistance in the Norway rat and guidelines for the management of resistant rat infestations in the UK. Rodenticide Resistance Action Group, UK. Revised September 2018. 8 pp.

https://bpca.org.uk/write/MediaUploads/Documents/Other\%20Documents/Anticoagulant resistan ce in the Norway rat v3.pdf [accessed 21 January 2020].

Rost, S., Fregin, A., Ivankevicius, V., Conzelmann, E., Hörtnagel, K., Pelz, H-J., Lappegard, K., Seifried, E., Scharrer, I., Tuddenham, E.G., Müller, C.R., Strom, T.M. and Oldenburg, J. (2004) Mutations in VKORC1 cause warfarin resistance in multiple coagulation factor deficiency type 2 . Nature 427:537541.

Shore, R.F., Pereira, M.G., Potter, E.D. and Walker, L.A. (2015) Monitoring rodenticide residues in wildlife, Chapter 17 in Rodent Pests and their Control, 2nd Edition, ed. by Buckle, A,P, and Smith, R.H. CAB International, Wallingford, Oxon, UK. pp 346-365. 
820 Shore, R.F., Walker, L.A., Potter, E.D., Chaplow, J.S., Pereira, M.G., Sleep, D. and Hunt, A. (2019)

821 Second generation anticoagulant rodenticide residues in barn owls 2018. Centre for Ecology \&

822 Hydrology contract report to the Campaign for Responsible Rodenticide Use (CRRU) UK, pp. 24.

823 Centre forAvailable at: https://pbms.ceh.ac.uk/sites/default/files/stewardship-2018-owls FINAL.pdf

824 [accessed 07.01.20].

825 Shore, R.F. and Coerdassier, M. (2018) Primary exposure and effects in non-target animals, Chapter 6

826 in Anticoagulant Rodenticides and Wildlife, eds. van den Brink, N.W., Elliott, J.E., Shore, R.F. and

827 Rattner, B.A. Springer International Publishing AG, Cham, Switzerland. pp 135-157.

828 Smith, R.H. and Shore, R.F. (2015) Environmental Impacts of Rodenticides. Chapter 16 in Rodent

829 Pests and their Control, 2nd Edition, eds. Buckle, A.P. and Smith, R.H. CAB International,

830 Wallingford, Oxon, UK. pp 330-345. 


\begin{tabular}{|l|l|l|l|l|l|}
\hline Bait type & $\begin{array}{l}\text { Active } \\
\text { substance }\end{array}$ & $\begin{array}{l}\text { Active } \\
\text { substance } \\
\text { conc. }(\mathrm{ppm})\end{array}$ & $\begin{array}{l}\text { Trial } \\
\text { site(s) }\end{array}$ & $\begin{array}{l}\text { Quantity of } \\
\text { bait applied } \\
\text { per baiting } \\
\text { point }(\mathrm{g})\end{array}$ & $\begin{array}{l}\text { Replenishment } \\
\text { frequency }\end{array}$ \\
\hline Pellet (commercial) & difenacoum & $50 \mathrm{ppm}$ & 1 and 2 & $100-300$ & Twice weekly \\
\hline Pellet (commercial) & bromadiolone & $50 \mathrm{ppm}$ & 3 and 4 & $150-300$ & Twice weekly \\
\hline $\begin{array}{l}\text { Wax block }(20 \mathrm{~g}) \\
\text { (experimental) }\end{array}$ & brodifacoum & $23 \mathrm{ppm}$ & 5 & $20-60$ & $\begin{array}{l}\text { Three times } \\
\text { weekly }\end{array}$ \\
\hline Pellet (commercial) & brodifacoum & $23 \mathrm{ppm}$ & 6 & 50 & $\begin{array}{l}\text { Three times } \\
\text { weekly }\end{array}$ \\
\hline
\end{tabular}

Table 1. Rodenticide baits used, the concentrations of the active substance, application rates and the frequency of bait replenishment in the six field trials. 


\begin{tabular}{|c|l|l|c|c|c|}
\hline Site & Dates of trial & Active substance & $\begin{array}{c}\text { No. tracking } \\
\text { patches }\end{array}$ & $\begin{array}{c}\text { No. census bait } \\
\text { points }\end{array}$ & $\begin{array}{c}\text { No. poisoned } \\
\text { bait points }\end{array}$ \\
\hline 1 & $13.02 .2009-08.05 .2009$ & difenacoum & 45 & 58 & 57 \\
\hline 2 & $26.10 .2009-24.01 .2010$ & difenacoum & 39 & 82 & 90 \\
\hline 3 & $13.02 .2009-21.04 .2009$ & bromadiolone & 54 & 78 & 77 \\
\hline 4 & $26.10 .2009-24.01 .2010$ & bromadiolone & 46 & 94 & 97 \\
\hline 5 & $18.04 .2016-29.07 .2016$ & brodifacoum & 35 & 50 & 55 \\
\hline 6 & $05.05 .2016-23.12 .2016$ & brodifacoum & 32 & 50 & $90^{*}$ \\
\hline
\end{tabular}

Note: $* 41$ rat burrows were also baited for a 13 -day period.

Table 2. The dates of trials, numbers of tracking, census bait and poisoned bait points used on the six farms. 


\begin{tabular}{|c|c|c|c|c|}
\hline $\begin{array}{l}\text { Trial } \\
\text { site }\end{array}$ & Active substance & $\begin{array}{l}\text { Sex and no. of } \\
\text { animals tested }\end{array}$ & $\begin{array}{c}\text { Doses } \\
\text { administered }\end{array}$ & $\begin{array}{c}\text { \% non- } \\
\text { responders }\end{array}$ \\
\hline \multirow[t]{4}{*}{1} & \multirow[t]{2}{*}{ bromadiolone } & Female $(n=10)$ & $\begin{array}{l}5.00 \mathrm{mg} \cdot \mathrm{kg}^{-1} \\
\left(8 x \mathrm{ED}_{50}\right)\end{array}$ & 70.0 \\
\hline & & Male $(n=7)$ & $\begin{array}{l}1.41 \mathrm{mg} \cdot \mathrm{kg}^{-1} \\
\left(3 \times \mathrm{ED}_{50}\right)\end{array}$ & 71.0 \\
\hline & \multirow[t]{2}{*}{ difenacoum } & Female $(n=9)$ & $\begin{array}{l}4.74 \mathrm{mg} \cdot \mathrm{kg}^{-1} \\
\left(6 \times \mathrm{ED}_{50}\right)\end{array}$ & 44.4 \\
\hline & & Male $(n=6)$ & $\begin{array}{l}1.95 \mathrm{mg} \cdot \mathrm{kg}^{-1} \\
\left(3 \times \mathrm{ED}_{50}\right)\end{array}$ & 83.3 \\
\hline \multirow[t]{4}{*}{2} & \multirow[t]{2}{*}{ bromadiolone } & Female $(n=5)$ & $\begin{array}{l}5.00 \mathrm{mg} \cdot \mathrm{kg}^{-1} \\
\left(8 \times \mathrm{ED}_{50}\right)\end{array}$ & 60.0 \\
\hline & & Male $(n=5)$ & $\begin{array}{l}1.41 \mathrm{mg} \cdot \mathrm{kg}^{-1} \\
\left(3 \times \mathrm{ED}_{50}\right)\end{array}$ & 60.0 \\
\hline & \multirow[t]{2}{*}{ difenacoum } & Male $(n=5)$ & $\begin{array}{l}1.95 \mathrm{mg} \cdot \mathrm{kg}^{-1} \\
\left(3 \times \mathrm{ED}_{50}\right)\end{array}$ & 60.0 \\
\hline & & Female $(n=5)$ & $\begin{array}{l}4.74 \mathrm{mg} \cdot \mathrm{kg}^{-1} \\
\left(6 \mathrm{xED}_{50}\right)\end{array}$ & 40.0 \\
\hline \multirow[t]{3}{*}{3} & \multirow[t]{2}{*}{ bromadiolone } & Female $(n=5)$ & $\begin{array}{l}5.00 \mathrm{mg} \cdot \mathrm{kg}^{-1} \\
\left(8 \times \mathrm{xD}_{50}\right)\end{array}$ & 40.0 \\
\hline & & Male $(n=8)$ & $\begin{array}{l}1.41 \mathrm{mg} \cdot \mathrm{kg}^{-1} \\
\left(3 \times \mathrm{ED}_{50}\right)\end{array}$ & 100.0 \\
\hline & difenacoum & Female $(n=1)$ & $\begin{array}{l}4.74 \mathrm{mg} \cdot \mathrm{kg}^{-1} \\
\left(6 \mathrm{xED}_{50}\right)\end{array}$ & 100.0 \\
\hline \multirow[t]{4}{*}{4} & \multirow[t]{2}{*}{ bromadiolone } & Female $(n=6)$ & $\begin{array}{l}5.00 \mathrm{mg} \cdot \mathrm{kg}^{-1} \\
\left(8 \times \mathrm{xD}_{50}\right)\end{array}$ & 33.3 \\
\hline & & Male $(n=2)$ & $\begin{array}{l}1.41 \mathrm{mg} \cdot \mathrm{kg}^{-1} \\
\left(3 \times \mathrm{ED}_{50}\right)\end{array}$ & 50.0 \\
\hline & \multirow[t]{2}{*}{ difenacoum } & Female $(n=11)$ & $\begin{array}{l}4.74 \mathrm{mg} \cdot \mathrm{kg}^{-1} \\
(6 \times \text { ED 50) }\end{array}$ & 63.3 \\
\hline & & Male $(n=13)$ & $\begin{array}{l}1.95 \mathrm{mg} \cdot \mathrm{kg}^{-1} \\
\left(3 \times \mathrm{ED}_{50}\right)\end{array}$ & 53.4 \\
\hline
\end{tabular}

Table 3. The results of the blood clotting response tests conducted on rats from four of the six treated farms. Doses administered are shown as both absolute values and as multiples of the ED50 for fully susceptible animals. Dates of the trials are given in Table 2. 


\begin{tabular}{|c|c|c|c|c|c|c|}
\hline Site & $\begin{array}{c}\text { Number of } \\
\text { animals }\end{array}$ & $\begin{array}{c}\text { Wild type } \\
\text { (susceptible) }\end{array}$ & Heterozygous & Homozygous & $\begin{array}{c}\text { Sequencing } \\
\text { failed }\end{array}$ & $\%$ resistant \\
\hline 1 & 32 & 0 & 1 & 30 & 1 & 100.0 \\
\hline 2 & 27 & 0 & 3 & 24 & 0 & 100.0 \\
\hline 3 & 13 & 0 & 1 & 12 & 0 & 100.0 \\
\hline 4 & 20 & 0 & 2 & 18 & 0 & 100.0 \\
\hline 5 & 9 & 1 & 1 & 5 & 2 & 85.7 \\
\hline 6 & 10 & 0 & 5 & 4 & 1 & 100.0 \\
\hline totals & 111 & 1 & 13 & 93 & 4 & \\
\hline
\end{tabular}

Table 4. Results of DNA sequencing for the $L 120 Q$ resistance mutation among rats taken from the trial sites. Dates of the trials are given in Table 2. 


\begin{tabular}{|c|c|c|c|c|c|c|c|c|}
\hline Site & $\begin{array}{l}\text { Total pre- } \\
\text { treatment } \\
\text { census bait } \\
\text { take }\left(\mathrm{kg}^{-1}\right)\end{array}$ & $\begin{array}{l}\text { Highest daily } \\
\text { pre- } \\
\text { treatment } \\
\text { census bait } \\
\text { take }\left(\mathrm{kg}^{-1}\right)\end{array}$ & $\begin{array}{l}\text { Total pre- } \\
\text { treatment } \\
\text { track score }\end{array}$ & $\begin{array}{c}\text { Highest daily } \\
\text { pre- } \\
\text { treatment } \\
\text { track score }\end{array}$ & $\begin{array}{l}\text { Total post- } \\
\text { treatment } \\
\text { census bait } \\
\text { take }\left(\mathrm{kg}^{-1}\right)\end{array}$ & $\begin{array}{l}\text { Highest daily } \\
\text { post- } \\
\text { treatment } \\
\text { census bait } \\
\text { take }\left(\mathrm{kg}^{-1}\right)\end{array}$ & $\begin{array}{l}\text { Total post- } \\
\text { treatment } \\
\text { track score }\end{array}$ & $\begin{array}{l}\text { Highest daily } \\
\text { post- } \\
\text { treatment } \\
\text { track score }\end{array}$ \\
\hline 1* & 6.87 & 2.20 & 242 & 55 & 7.89 & 1.86 & 286 & 58 \\
\hline 2 & 33.36 & 10.57 & 418 & 115 & 13.20 & 4.20 & 169 & 45 \\
\hline 3 & 9.20 & 2.73 & 154 & 43 & 2.83 & 0.92 & 94 & 27 \\
\hline 4 & 15.07 & 5.49 & 285 & 84 & 17.80 & 5.57 & 323 & 87 \\
\hline 5 & 4.88 & 1.37 & 172 & 50 & 0.02 & 0.01 & 0 & 0 \\
\hline 6 & 9.78 & 3.18 & 336 & 96 & 0.05 & 0.03 & 4 & 3 \\
\hline
\end{tabular}

Table 5. Results of pre- and post-treatment census baiting and tracking at the six experimental sites. 


\begin{tabular}{|c|c|c|c|c|c|c|}
\hline \multirow[t]{2}{*}{ Site } & \multirow[t]{2}{*}{$\begin{array}{l}\text { Active substance } \\
\text { (conc. ppm) }\end{array}$} & \multirow{2}{*}{$\begin{array}{l}\text { Maximum daily } \\
\text { take of pre- } \\
\text { treatment census } \\
\text { bait }(\mathrm{kg})^{\S}\end{array}$} & \multirow{2}{*}{$\begin{array}{c}\text { Total } \\
\text { quantity of } \\
\text { rodenticide } \\
\text { used }(\mathrm{kg})\end{array}$} & \multirow{2}{*}{$\begin{array}{l}\text { Total quantity } \\
\text { of active } \\
\text { substance } \\
\text { applied (g) }\end{array}$} & \multicolumn{2}{|c|}{$\begin{array}{l}\text { Estimated mortality } \\
(\%)^{*}\end{array}$} \\
\hline & & & & & $\begin{array}{l}\text { Census } \\
\text { baiting }\end{array}$ & $\begin{array}{l}\text { Track } \\
\text { Score }\end{array}$ \\
\hline 1 & difenacoum (50ppm) & $2.20(110)$ & 28.57 & 1.43 & 15.5 & +5.5 \\
\hline 2 & difenacoum (50ppm) & $10.57(529)$ & 59.24 & 2.96 & 60.3 & 60.9 \\
\hline 3 & bromadiolone (50 ppm) & $2.73(136)$ & 17.67 & 0.88 & 66.3 & 37.2 \\
\hline 4 & bromadiolone (50 ppm) & $5.49(275)$ & 43.19 & 2.16 & +1.5 & +3.6 \\
\hline 5 & brodifacoum (23 ppm) & $1.37(69)$ & 4.38 & 0.10 & 99.3 & 100.0 \\
\hline 6 & brodifacoum (23 ppm) & $3.18(159)$ & $9.68 t$ & 0.22 & 98.4 & 96.9 \\
\hline
\end{tabular}

Notes: $\quad$ values in brackets are the estimated numbers of rats present at the start of the treatments (assumptions are given in the text)

* mortality estimates preceded by + indicate estimated population growth during treatment

+ includes burrow bait that was applied but some of which was probably not consumed

Table 6. The results of efficacy assessments conducted at the six trial sites. The maximum daily pre-

treatment census bait take is shown as an indirect measure of the sizes of the initial infestations. 
Click here to download high resolution image

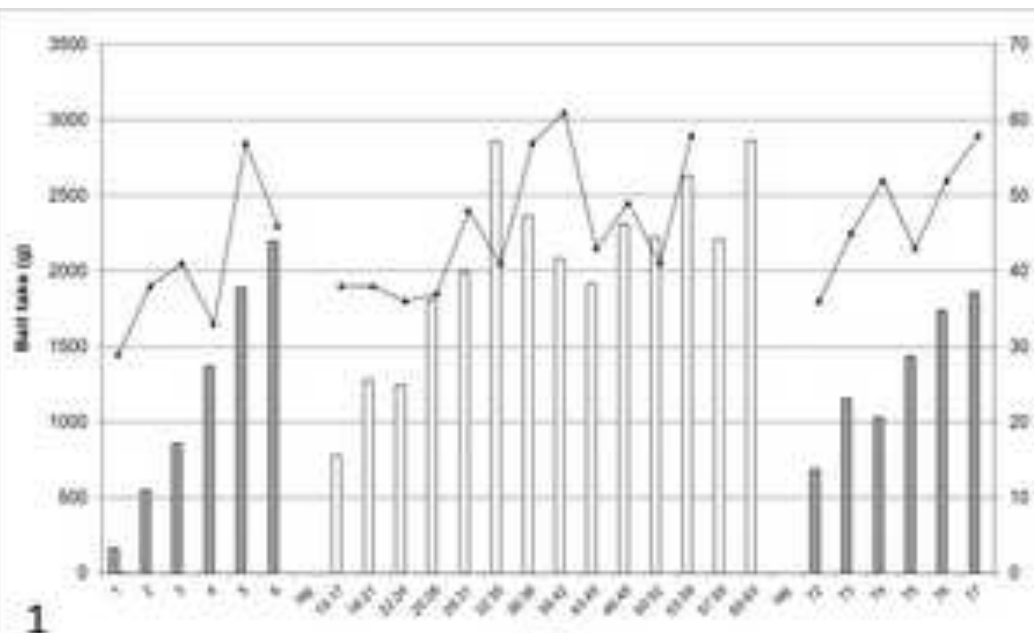

Don

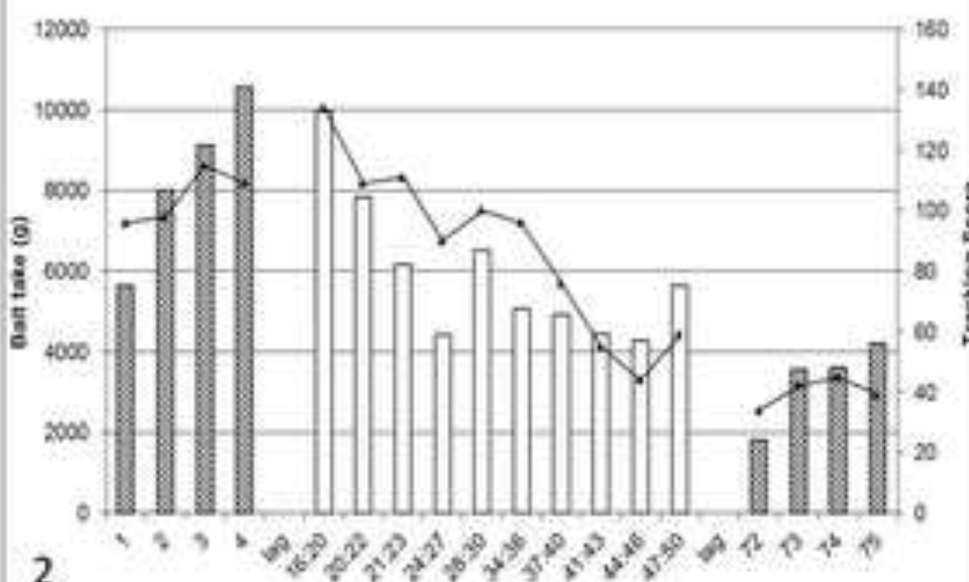

Dage

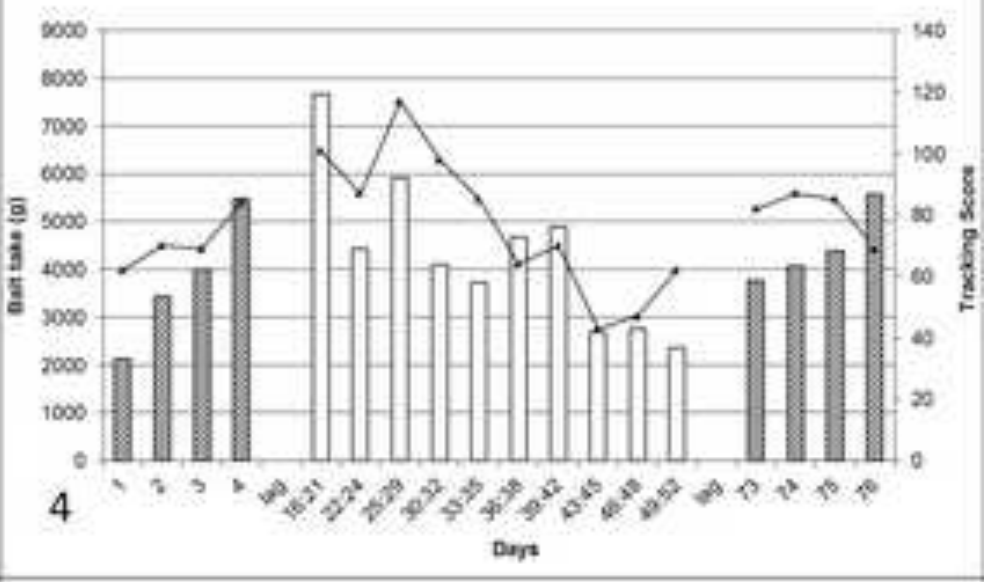

5

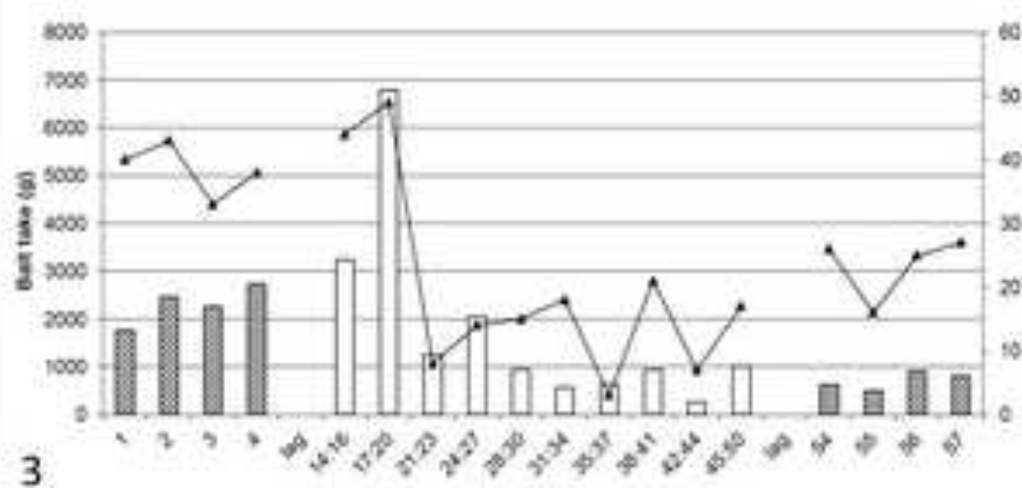

Dors

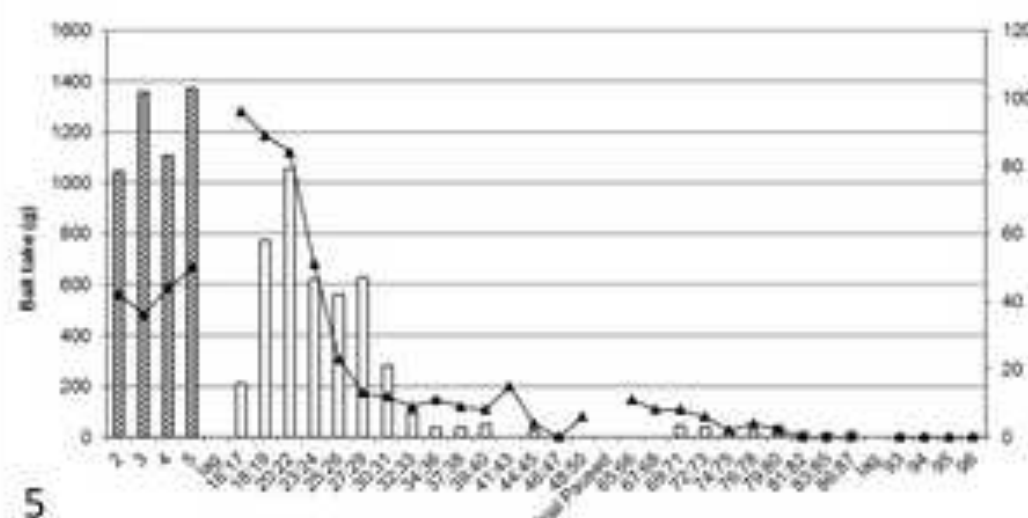

ans

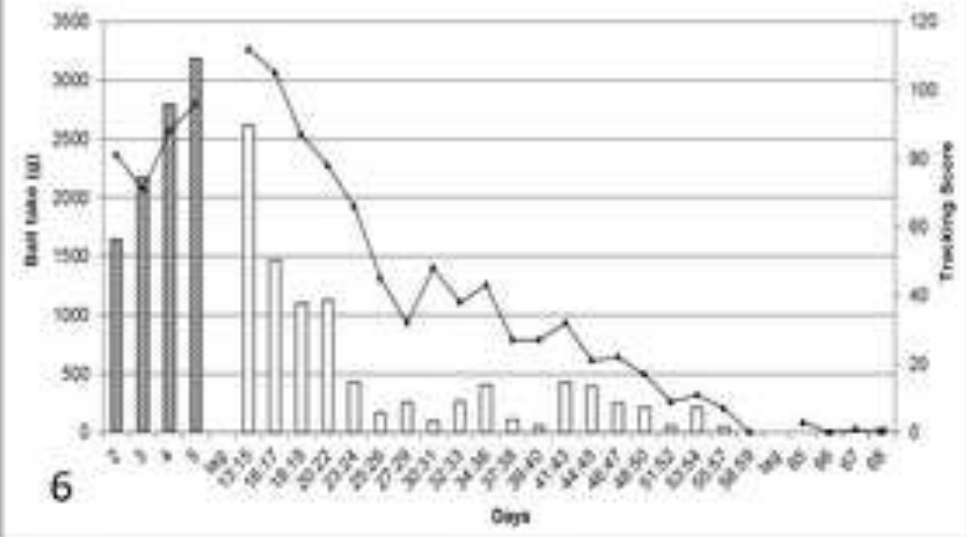


Highlights

- Field trials were conducted with three anticoagulants in Hampshire/Berkshire UK

- Six farm sites were used where $87 \%$ of Norway rats were L120Q homozygous resistant

- Bromadiolone and difenacoum were ineffective and should not be used against L120Q

- Brodifacoum was fully effective, with lower anticoagulant environmental emissions

- Rodenticide stewardship is in place, with resistance and environmental monitoring 


\section{Declaration of interests}

The authors declare that they have no known competing financial interests or personal relationships that could have appeared to influence the work reported in this paper.

$\bigotimes$ The authors declare the following financial interests/personal relationships which may be considered as potential competing interests:

The study was funded by Syngenta AG, Basel, Switzerland. Dr Alex Cornish, of Syngenta, provided comment on some aspects of the study including application rates for the brodifacoum formulations. The funding company and Dr Cornish, however, played no part in collection, analysis and interpretation of data, in writing the report and in the decision to submit the article for publication. 
Alan Buckle: Conceptualization; Formal analysis; Funding acquisition; Investigation; Methodology; Project administration; Supervision; Writing original draft; Writing - review \& editing. Clare Jones: Data curation; Formal analysis; Investigation; Writing - review \& editing. David Rymer: Data curation; Formal analysis; Investigation. Emily Coan: Data curation; Formal analysis; Investigation. Colin Prescott: Conceptualization; Data curation; Formal analysis; Funding acquisition; Investigation; Methodology; Project administration; Resources; Supervision; Writing - review. 